\title{
Role of glycosylation in TGF- $\beta$ signaling and epithelial-to-mesenchymal transition in cancer
}

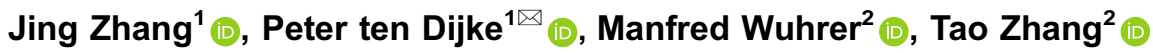 \\ ${ }^{1}$ Oncode Institute and Cell Chemical Biology, Leiden University Medical Center, 2300 RC Leiden, The Netherlands \\ ${ }^{2}$ Center for Proteomics and Metabolomics, Leiden University Medical Center, Leiden, The Netherlands \\ $\triangle$ Correspondence: P.ten_Dijke@lumc.nl (P. ten Dijke) \\ Received March 24, 2020 Accepted May 29, 2020
}

\begin{abstract}
Glycosylation is a common posttranslational modification on membrane-associated and secreted proteins that is of pivotal importance for regulating cell functions. Aberrant glycosylation can lead to uncontrolled cell proliferation, cell-matrix interactions, migration and differentiation, and has been shown to be involved in cancer and other diseases. The epithelial-to-mesenchymal transition is a key step in the metastatic process by which cancer cells gain the ability to invade tissues and extravasate into the bloodstream. This cellular transformation process, which is associated by morphological change, loss of epithelial traits and gain of mesenchymal markers, is triggered by the secreted cytokine transforming growth factor- $\beta$ (TGF- $\beta$ ). TGF- $\beta$ bioactivity is carefully regulated, and its effects on cells are mediated by its receptors on the cell surface. In this review, we first provide a brief overview of major types of glycans, namely, $\mathrm{N}$-glycans, $\mathrm{O}$-glycans, glycosphingolipids and glycosaminoglycans that are involved in cancer progression. Thereafter, we summarize studies on how the glycosylation of TGF- $\beta$ signaling components regulates TGF- $\beta$ secretion, bioavailability and TGF- $\beta$ receptor function. Then, we review glycosylation changes associated with TGF- $\beta$-induced epithelial-tomesenchymal transition in cancer. Identifying and understanding the mechanisms by which glycosylation affects TGF- $\beta$ signaling and downstream biological responses will facilitate the identification of glycans as biomarkers and enable novel therapeutic approaches.
\end{abstract}

KEYWORDS cancer, epithelial-to-mesenchymal transition, glycosphingolipids, $\mathrm{N}$-glycosylation, $\mathrm{O}$ glycosylation, transforming growth factor $-\beta$

\section{INTRODUCTION}

Glycans are part of glycoproteins, proteoglycans, glycosaminoglycans (GAGs) and glycolipids which cover the cell surface. They play key roles in different biological and cellular functions. Protein glycosylation includes $\mathrm{N}$-linked glycosylation (in which glycan is attached to a nitrogen of an asparagine (Asn) residue of a protein), O-linked glycosylation (in which glycans are attached to a serine (Ser) or threonine (Thr) residue of a protein), $C$-mannosylation (in which a mannose is attached to a Tryptophan (Trp) of a protein), phospho-glycosylation and glypiation (Krasnova and Wong, 2016; Reily et al., 2019). When proteins are heavily glycosylated and contain a core protein with one or more GAG chain(s) covalently attached via xylose(s), they are named proteoglycans (lozzo and Schaefer, 2015). Glycolipids are carbohydrate-modified lipids, and this type of glycoconjugate includes glycosphingolipids (GSLs) (D'Angelo et al., 2013). Perturbed glycosylation has been linked to many developmental disorders, diseases and tumor progression (Pinho and Reis, 2015; Rodrigues et al., 2018). Many glycans on the surface of cancer cells have recently been identified as critical regulators controlling several pathological processes during tumor progression (Dube and Bertozzi, 2005; Freire-de-Lima, 2014).

Alterations in protein- and lipid-linked glycans are associated with a multitude of biological processes related to cancer. Because of their special cell-surface position, glycans are of critical importance in controlling cell-cell communication, signal transduction and receptor activation. 
Various glycan structures have already been characterized as hallmarks of cancer which allow cancer to survive, proliferate, become migratory and invasive (Wang et al., 2019). Currently, glycoproteins are the most used cancer biomarkers in the clinic, such as alpha-fetoprotein (AFP) for hepatocellular carcinoma (Leerapun et al., 2007; Cheng et al., 2014), cancer antigen 125 (CA125) for ovarian cancer (Dochez et al., 2019), carcinoembryonic antigen (CEA) for colon cancer (Auclin et al., 2018), and prostate specific antigen (PSA) for prostate cancer (Albertsen, 2018). In addition, glycan-related carbohydrate antigen 19-9 (CA199), also known as sialyl-Lewis $A$, is a key hallmark used routinely in the management of pancreatic ductal adenocarcinoma (PDAC) (O'Brien et al., 2015). It has a 79\%-81\% sensitivity and $82 \%-90 \%$ specificity for diagnosis of pancreatic cancer in symptomatic patients (Ballehaninna and Chamberlain, 2012). Proteoglycans especially glypican-1 (GPC1), which enriched on cancer-cell-derived exosomes, may play a role as a biomarker to detect early stages of pancreatic cancer (Melo et al., 2015).

Tumor initiation and progression mediated by (epi)genetic changes result in altered gene functions, including gain-offunction modifications in proto-oncogenes and loss-of-function modifications in tumor suppressor genes (Hanahan and Weinberg, 2000). Whereas growth factors, such as plateletderived growth factor (PDGF) and epidermal growth factor (EGF), become overly active, the cytostatic action of growth inhibitory factors, such as transforming growth factor- $\beta$ (TGF- $\beta$ ), is lost or corrupted (Heldin, 2004). These changes impact the cancer cell phenotype, which may be associated with increased proliferation, migration and invasion and/or creation of a favorable tumor microenvironment that drives angiogenesis, metastasis and/or immune evasion (Hanahan and Weinberg, 2011). The epithelial-to-mesenchymal transition (EMT) is an important step in cancer cell invasion and migration and is characterized by a change in cell morphology from a cobble stone epithelial-type shape to an elongated spindle-shaped fibroblast-like appearance (Derynck and Weinberg, 2019; Lu and Kang, 2019). The multifunctional cytokine TGF- $\beta$ is known to be a crucial driver of EMT in various (cancer) cells (Derynck et al., 2014; Hao et al., 2019). TGF- $\beta$ transduces signals via a single-pass transmembrane Ser/Thr kinase receptors and co-receptors, which have glycosylated extracellular domains (Heldin and Moustakas, 2016). Extracellular (and intracellular) signaling through TGF- $\beta$ is intricately regulated, involving the glycosylation of cell surface TGF- $\beta$-binding proteins. These changes in the glycosylation are of critical importance for the cellular responses induced by TGF- $\beta$, including the EMT.

In this review, we first provide a general overview of glycosylation modifications and their roles in cancer. Next, we discuss advances in the understanding of how the glycosylation of TGF- $\beta$-signaling components affects their function. Thereafter, we review the changes in glycosylation in response to TGF- $\beta$ that have been documented and focus in particular on those that are involved in TGF- $\beta$-induced EMT.
Furthermore, we conclude by offering perspectives on how insights into the interplay between glycosylation and TGF- $\beta$ signaling can be used for future diagnostic and therapeutic gains for cancer patients.

\section{GLYCOCONJUGATES AND GLYCOSYLATION}

The biosynthesis of diverse glycan structures is based on the tight regulation and dynamic action of different enzymes, such as glycosyltransferases and glycosidases ( $\mathrm{Xu}$ et al., 2018). Glycoproteins may carry $N$-linked glycans covalently attached to the nitrogen on the side chain of an asparagine residue. $\mathrm{N}$-glycans contain a common pentasaccharide core region consisting of Mana1,6 (Mana1,3) Man$\beta 1,4 \mathrm{GlcNAc} \beta 1,4 \mathrm{GlcNAc} \beta 1-A s n \quad\left(\mathrm{Man}_{3}-\mathrm{GlcNAc}_{2} \mathrm{Asn}\right)$ (Fig. 1A). They can be elaborated further, resulting in three main $\mathrm{N}$-glycan types: oligomannosidic, hybrid and complextype structures (Fig. 1A). O-linked glycans (O-glycans) are attached to a side chain at serine or threonine residues. $O$ linked $\alpha-N$-acetylgalactosamine (O-GalNAc) or mucin-type O-glycan is a common type of O-glycan initiated via a single $\mathrm{N}$-acetylgalactosamine residue that is attached to a Ser/Thr residue of a protein by glycosyltransferases (GTs) (Fig. 1A) (Brockhausen and Stanley, 2015). Once this initial structure is formed, additional sugars can be added. There are other types of $\mathrm{O}$-glycans, such as $\mathrm{O}$-linked $\mathrm{N}$-acetylglucosamine (O-GlcNAc) or those attached to proteins via O-mannose, Ogalactose, O-fucose or O-glucose (Ma and Hart, 2014; Haltiwanger et al., 2015; Pinho and Reis, 2015).

GSLs are the most common glycolipids in vertebrates and are composed of a carbohydrate moiety linked to a ceramide. GSLs can be grouped along two precursor groups, galactosylceramides (GalCer) and glucosylceramides (GlcCer), depending on the initial monosaccharide, which is attached via a $\beta$-glycoside bond to a ceramide molecule (D'Angelo et al., 2013). The latter group consists of three major series based on the synthesis pathways and core structures: gangliosides, (iso)globosides, and (neo)lactoseries GSLs (Fig. 1B) (Schnaar and Kinoshita, 2015). Many cell surface proteins are associated with GSLs, resulting in important roles for GSLs in regulating cell proliferation (Regina Todeschini and Hakomori, 2008), differentiation (Breimer et al., 2017) and tumor progression (Furukawa et al., 2019).

Proteoglycans (PGs) are a ubiquitous family of glycoconjugates composed of a core protein and one or several covalently attached GAG chains (lozzo and Schaefer, 2015). GAGs are a family of highly sulfated and linear polysaccharides with repeating disaccharide unites (Fig. 1A). Based on the difference of repeating unites, GAGs are further divided into four groups: hyaluronan, chondroitin sulfate, heparan sulfate and keratan sulfate (Lindahl et al., 2015). Different forms of proteoglycans are present in nearly all extracellular matrices of connective tissues and are involved in regulating collagen fibril formation and the activity of 

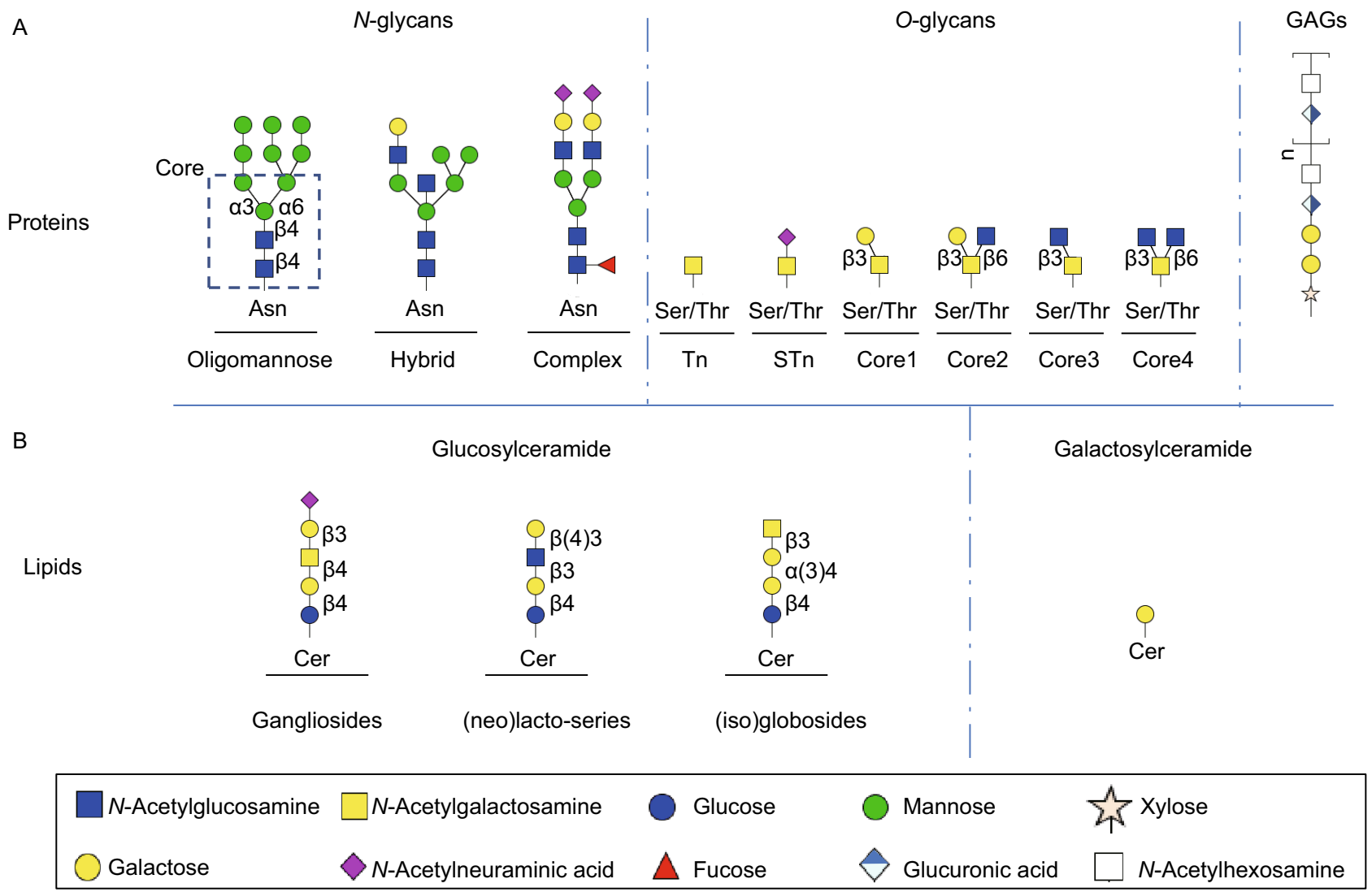

Figure 1. Major classes of glycans in mammalian cells. (A) $\mathrm{N}$-glycans are linked to asparagine (Asn) residues of proteins and contains three different types which are oligomannose, hybrid and complex structures. These three $\mathrm{N}$-glycans share a common core structure (indicated in dashed box). Mucin-type O-glycans are attached to a subset of serines (Ser) or threonines (Thr) and start with a single $\mathrm{N}$-acetylgalactosamine (also known as Tn-antigen) then is extended by galactose or sialic acids or GlcNAc with four different cores. In addition, the O-xylose linked, non-branched glycosaminoglycans (GAG) are a large glycan family. (B) Glycosphigolipids (GSLs) include two precursor groups, galactosylceramides and glucosylceramides. The latter group contains three core structures: gangliosides, (iso)globosides, and (neo)lacto-series GSLs.

secreted factors involved in communication between cells, including TGF- $\beta$.

\section{GLYCOSYLATION ALTERATIONS IN CANCER}

Many glycoconjugates, such as glycoproteins and glycolipids, are found on the outer surface of the cellular membrane. Because of this special position, glycans play essential roles in recognizing the extracellular matrix, interacting with other cells in the cellular microenvironment, regulating the binding of canonical protein ligands to their specific receptors and resulting in changes in cell-cell adhesion and signal transduction (Fuster and Esko, 2005; Pinho and Reis, 2015; Rodrigues et al., 2018). Changes in glycosylation of lipids and cell surface proteins have been shown to be associated with defects in basic biological processes observed in cancer, such as cell-cell adhesion (Zhao et al., 2008; Pinho et al., 2009; Pinho et al., 2013), cell-matrix interaction (Zhao et al., 2008), intercellular and intracellular signaling (Boscher et al., 2011; Gomes et al., 2013; Takeuchi and Haltiwanger, 2014), and cellular metabolism (Dennis et al., 2009; Bassaganas et al., 2014). In the remaining part of this section, we provide a few examples for illustration.

Epithelial cadherin (E-cadherin) is a cell-cell adhesion molecule, and its dysfunction or inactivation can contribute to cancer progression (Mendonsa et al., 2018). E-cadherin can be modified with $\beta 1,6-N$-acetylglucosamine $(\beta 1,6 \mathrm{GlcNAc})$ branched structures, which are catalyzed by $\mathrm{N}$-acetylglucosaminyltransferase $\mathrm{V}$ (MGAT5) and then become destabilized (Taniguchi and Kizuka, 2015). The disorganization of E-cadherin/catenin complex formation can result in an impaired cell-cell aggregation and epithelial cells acquiring an invasive phenotype (Pinho et al., 2013).

Integrins, as transmembrane receptors, are involved in extracellular matrix (ECM)-cell and cell-cell interactions as 
well as signal transduction (Marsico et al., 2018). Aberrant O-glycosylation on integrins can mediate the invasive phenotypes of hepatocellular carcinoma (HCC) tumor cells. Modification of integrin $\beta 1$ by core $1 \beta 1,3$-galactosyltransferase (C1GALT1) regulates integrin activity, and overexpression of $C 1 G A L T 1$ results in increased $T$ antigen and sialyl T antigen levels and induces $\mathrm{HCC}$ cell migration and invasion (Liu et al., 2014a; Liu et al., 2014b). Core fucosylation is essential for the function of integrin and integrinmediated cell migration and signal transduction in embryonic fibroblasts (Zhao et al., 2006).

Cell surface glycans can promote or hinder the cellular receipt of signals from outside by regulating the glycosylation of signaling specific receptors on the surface (Ferreira et al., 2018). Numerous key growth factors, such as EGF, hepatocyte growth factor (HGF), vascular endothelial growth factor (VEGF) and TGF- $\beta$ (the focus of this review, see below), are involved in regulating tumor growth, invasion and metastasis (Lau et al., 2007). Altered glycosylation of the receptors for these growth factors can modulate their turnover, interaction with ligands and recruitment of other signaling proteins (Ferreira et al., 2018). For example, the $N$ glycan core fucosylation of EGFR is essential to regulate the EGFR-mediated intracellular signaling pathway. Knocking down fucosyltransferase 8 (FUT 8) blocked the phosphorylation of EGFR, decreased EGF-mediated signal transduction and inhibited EGF-mediated cellular growth. It has been proposed that the fucosylation of EGFR may promote its binding affinity for EGF or increase the propensity of EGFR to form dimers (Matsumoto et al., 2008). Moreover, the enrichment of gangliosides in the cell membrane has been shown to play a role in decreasing the phosphorylation of VEGFR2 and suppressing tumor angiogenesis in human endothelial cells (Mukherjee et al., 2008). Thus, studying glycosylation changes and unravelling how glycans modulate cellular signaling involved in cancer progression are of great importance and may potentially contribute to the development of novel therapeutic approaches.

\section{TGF- $\beta$ SIGNALING PATHWAY}

This review focuses on TGF- $\beta$, which is one of the key soluble factors in intercellular (mis)communication in cancer (Colak and Ten Dijke, 2017; Batlle and Massague, 2019). Three distinct isoforms have been identified, i.e., TGF- $\beta 1$, TGF $-\beta 2$ and TGF $-\beta 3$. Here, we use TGF- $\beta$, unless a specific property has been shown for a specific isoform, in which case the isoform will be indicated. TGF- $\beta$ is secreted by cells as part of an inactive biological complex, in which the mature carboxy-terminal TGF- $\beta$ is noncovalently bound to its amino-terminal precursor fragment, also known as the latency-associated peptide (LAP) (Robertson and Rifkin, 2016). This small latent TGF- $\beta$ complex can be covalently associated with the latent TGF- $\beta$-binding protein (LTBP); together, they compose the large latent TGF- $\beta$ complex (Robertson et al., 2015). The LTBP facilitates the secretion of
TGF- $\beta$ and plays a role in targeting TGF- $\beta$ to particular extracellular stores by interacting with the extracellular matrix. Latent TGF- $\beta$ can be released via the action of specific proteases that cleave LAP or by mechanical forces in an integrin-dependent process (Fig. 2A) (Hyytiainen et al., 2004; Dong et al., 2014). Active TGF- $\beta$ is capable of binding to receptors with intrinsic serine/threonine kinase activity, i. e., TGF- $\beta$ type I (T $\beta R I)$ and TGF- $\beta$ type II (T $\beta R I I)$ receptors (Massague, 2000). TGF- $\beta$ initially binds with T $\beta R I I$, and thereafter, $T \beta R I$ is recruited, forming a heteromeric complex (Fig. 2B). Subsequently, the T $\beta$ RII kinase transphosphorylates the serine and threonine residues in the glycine-serinerich (GS) juxtamembrane domain of T $\beta R$ I (Heldin et al., 1997). This phosphorylation leads to the activation of the $T \beta R I$ kinase and initiation of intracellular signaling. Intracellular TGF- $\beta$ signaling is largely mediated by the Sma and Mad related (SMAD) family of proteins. The activated T $\beta R I /$ T $\beta$ RII complex phosphorylates the two C-terminal serine residues of receptor-specific SMADs (R-SMADs), i.e., SMAD2 and SMAD3. Then, activated SMAD2/3 can form a complex with a common SMAD mediator, i.e., SMAD4, and translocate into the nucleus where the heteromeric complex modulates the transcription of target genes (Budi et al., 2017). In addition, posttranslational regulation of the receptors and SMADs help define their stability and functions, thus provide negative feedback mechanisms of TGF- $\beta / S M A D$ signaling ( $\mathrm{Xu}$ et al., 2012a). Therefore, by signaling through the canonical SMAD-dependent pathway, TGF- $\beta$ exerts its physiological and pathological actions through the transcriptional and posttranscriptional modulation of gene expression (Fig. 2B) (Hill, 2016). In addition to canonical SMAD-dependent signaling, SMAD-independent pathways can also be activated directly by ligand-occupied receptors to modulate downstream cellular responses in specific cell types (Zhang, 2017). Every step of the TGF- $\beta$ pathway is precisely controlled at the extracellular and intracellular levels, and the components engage in cross talk with factors in other pathways (Massague, 2012; Luo, 2017). Cell surface co-receptors such as endoglin and betaglycan (also termed CD105 and T $\beta$ RIII, respectively) play important roles in controlling the intensity, duration, specificity and diversity of signaling. Co-receptors are different from T $\beta R I$ and T $\beta R I$ in that they have larger extracellular domains but lack a functional enzymatic signaling motif (Nickel et al., 2018). Their domains contain a limited number of motifs, such as GAG modifications and the zona pellucida (ZP-1) domain (Kirkbride et al., 2005). It has been demonstrated that endoglin forms a complex with betaglycan and interacts with TGF- $\beta$ family ligands and/or type I and type II receptors (Nickel et al., 2018).

\section{TGF- $\beta$-INDUCED EMT IN CANCER PROGRESSION}

At the primary tumor site, the induction of the EMT program allows cells to acquire an invasive phenotype and drive cancer progression (Derynck and Weinberg, 2019; Lu and 


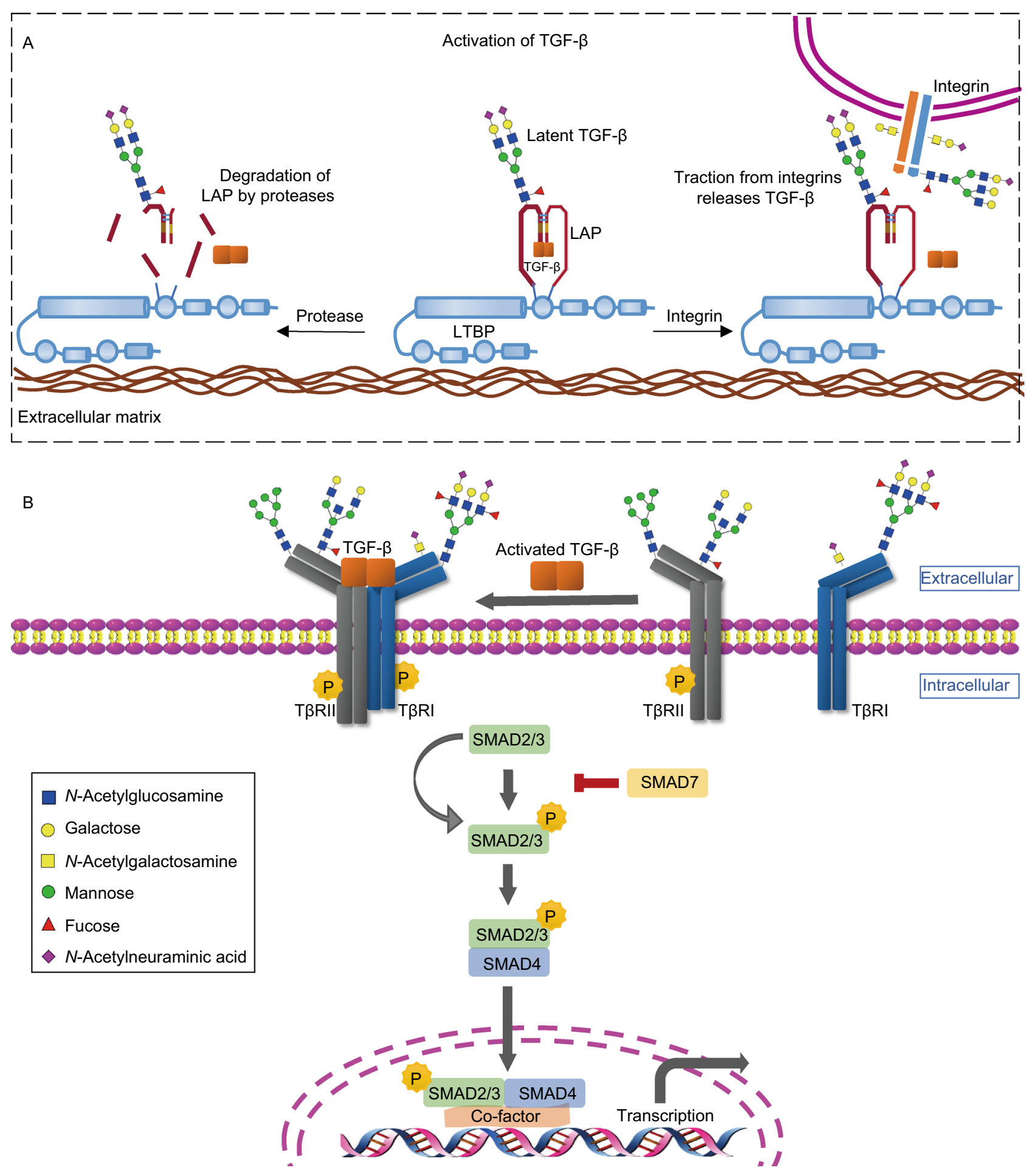


$4 \quad$ Figure 2. Glycosylation changes in TGF- $\beta$ activation and SMAD-dependent pathway. (A) Activation of TGF- $\beta$. The mature TGF- $\beta$ is noncovalently bound to the latency-associated peptide (LAP) and forms a latent TGF- $\beta$ complex with the latent TGF- $\beta$-binding protein (LTBP). TGF- $\beta$ can be released from the latent complex via cleavage of LAP by proteases digestion or integrin-dependent activation. The secreted TGF- $\beta$ precursor contains N-linked complex type structures. (B) Canonical SMAD-dependent pathway. Receptor signaling starts with active TGF- $\beta$ binding to the TGF- $\beta$ type II receptor (T $\beta$ RII), a constitutively activated kinase, which phosphorylates the TGF$\beta$ type I (T $\beta R I)$, both located in the plasma membrane. Then the actived TRRII/TRRI complex phosphorylates the SMAD2/3, which can form heteromeric complexes with SMAD4. These complexes translocate into nucleus where they can modulate the transcription of target genes. Both T $\beta R I I$ and T $\beta R I$ can be $N-$ and O-glycosylated. Oligomannosidic, branching structures and core fucosylation are important for the localization and function of receptors. In addition, Lewis antigens attached on T $\beta R I$ are observed in cancer cells.

Kang, 2019). The EMT is a reversible process in which epithelial cell-cell contacts and apical-basal polarity are lost/ decreased and in which cells acquire a mesenchymal phenotype with enhanced motility and invasion ability. The mesenchymal phenotype is apparent from the increased expression of cytoskeletal proteins, such as vimentin, and the upregulation of extracellular matrix proteins, such as collagens and fibronectin. In addition, the expression of epithelial markers, such as E-cadherin and Zona occludens protein (ZO-1), is downregulated concomitantly with an increase in the expression of mesenchymal marker proteins, including $\mathrm{N}$-cadherin (Katsuno et al., 2013; Moustakas and Heldin, 2016). However, the transition from an epithelial to a mesenchymal state is often incomplete and results in intermediate states that retain both epithelial and mesenchymal characteristics. Recently, new guidelines and definitions for epithelial to mesenchymal transition recommended to use the term of epithelial-mesenchymal plasticity (EMP) to describe the cells undergoing intermediate E/M phenotypic states (Yang et al., 2020). This plasticity refers to as partial EMT, hybrid E/M status, a metastable EMT state, EMT continuum and EMT spectrum (Yang et al., 2020). TGF- $\beta$ acts as a potent inducer of cancer progression by driving the EMT in both SMAD and non-SMAD signaling pathways. The TGF- $\beta$ SMAD signaling pathway directly activates the expression of EMT transcription factors, including the zinc finger transcription factors SNAIL and SLUG, two-handled zinc finger factors ZEB (zinc finger E-box-binding homeobox) 1 and ZEB2, and the basic helix-loop-helix factor TWIST (Katsuno et al., 2013; Moustakas and Heldin, 2016). TGF- $\beta$-induced non-SMAD pathways, such as the p38 MAPK (Yu et al., 2002) and PI3K/AKT/mTOR (Lamouille et al., 2012) pathways, also contribute to TGF- $\beta$-induced EMT.

\section{GLYCAN MODULATION OF TGF- $\beta$ SIGNALING COMPONENTS}

\author{
Effect of glycosylation on TGF- $\beta$ secretion \\ and bioavailability
}

Glycosylation of multiple proteins and complexes in the TGF$\beta$ signaling pathway regulates TGF- $\beta$ secretion and bioavailability. LAP, which is noncovalently associated with TGF- $\beta$ in an inactive complex, is glycosylated (Table 1) (Yang et al., 1997). $\beta 1$-LAP contains three $N$-glycosylation sites at residues 82, 136, and 176 (Purchio et al., 1988). In the Chinese hamster ovary cell line, inhibition of $\mathrm{N}$-glycosylation with either tunicamycin or an inhibitor of mannosidase II blocked the secretion of TGF- $\beta 1$ (Fig. 2A) (Sha et al., 1989; McMahon et al., 1996). In human embryonic kidney cells, a mutation at the second $N$-glycosylation site of $\beta 1$ LAP led to the blocked secretion of mature TGF- $\beta 1$ and the inhibition of TGF- $\beta 1$ bioactivity (Brunner et al., 1992; Lopez et al., 1992). The complex-type $N$-glycans present on secreted TGF- $\beta 1$ precursor have been implicated in the maintenance of the latent complex (Fig. 2A) as removal of complex oligosaccharides containing sialic acid from LAP resulted in the dissociation of the TGF- $\beta$ precursor from the latent complex (Miyazono and Heldin, 1989; Miyazono et al., 1992). In addition to LAP, LTBP has several potential $N$ glycosylation sites (Robertson and Rifkin, 2016), but whether the glycosylation of LTBP affects TGF- $\beta$ release is still unclear.

\section{Effect of glycosylation on TGF- $\beta$ receptor function}

Glycosylation affects the T $\beta$ RII localization in cells and interaction with TGF- $\beta$. Inhibiting or blocking the $N$-linked glycosylation of T $\beta$ RII using glycosylation inhibitors including tunicamycin and kifunensine or by mutating $N$-glycosylation sites prevents T $\beta$ RII proteins from being efficiently transported to the cell surface, resulting in decreased cellular sensitivity to TGF- $\beta$ (Kim et al., 2012) (Table 1). Additional evidence shows that both complex type and a oligomannosidic type modification of T $\beta R \mathrm{RI}$ are required for the successful cell surface transportation of T $\beta R$ II (Kim et al., 2012). Core fucosylation of T $\beta R I I$ and T $\beta R I$ has been studied as a key player in optimal TGF- $\beta$-receptor interactions and R-SMAD phosphorylation (Fig. 3, Table 1) (Venkatachalam and Weinberg, 2013). The TGF- $\beta$-induced phosphorylation of the SMAD2/3 proteins decreased when human renal proximal tubular epithelial cells were depleted of FUT8, a fucosyltransferase that specifically catalyzes core fucosylation of $N$-glycans (Lin et al., 2011). The data from Wang et al. (2005) also showed that lack of core fucosylation of T $\beta R I I$ results in the development of an emphysema-like phenotype in lung tissue. Mice deficient in Fut8 exhibited a significantly high level of matrix metalloproteinase (MMP) expression, which is consistent with a deficiency in TGF- $\beta 1$ signaling 

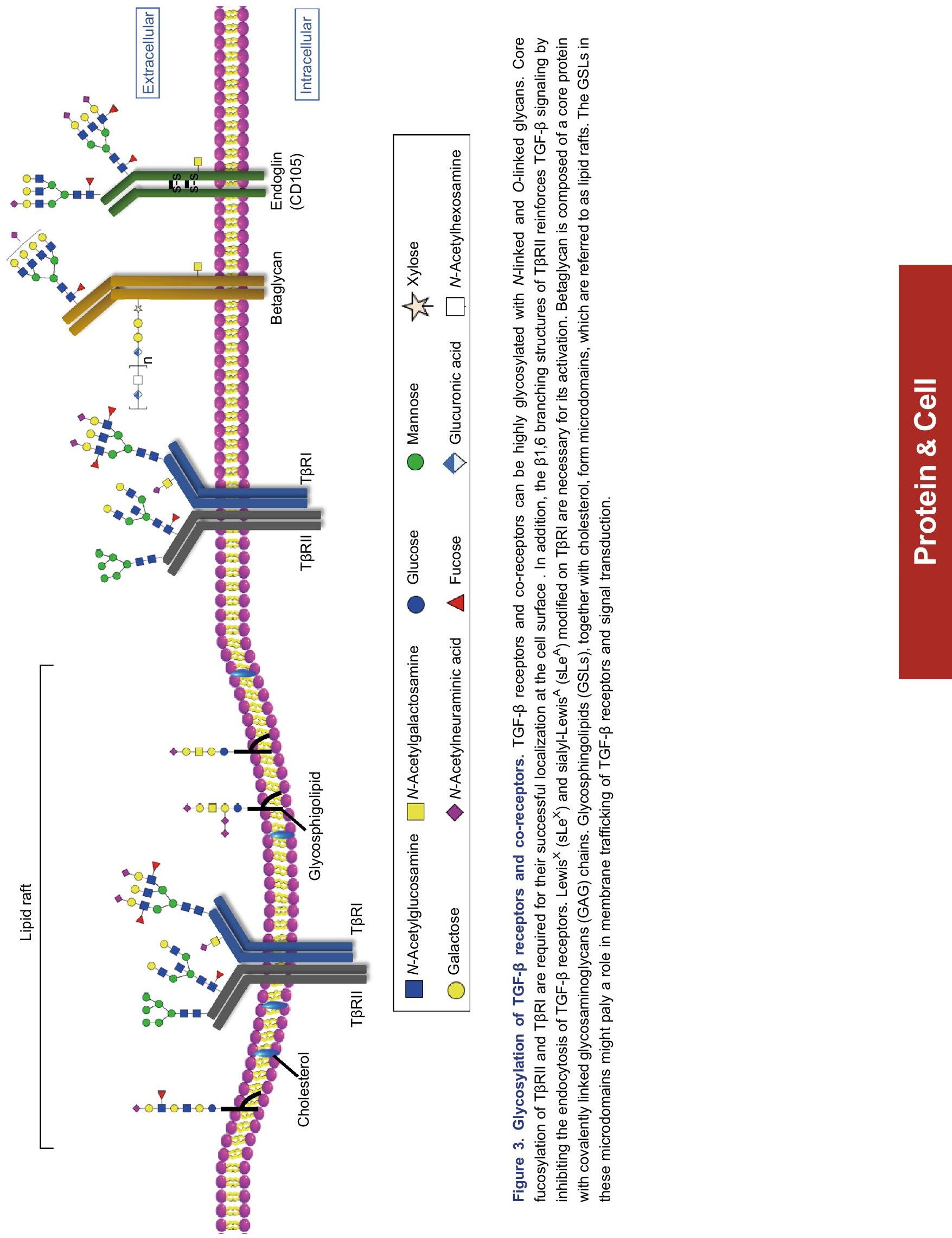

बㄷำ

过

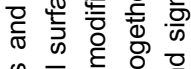

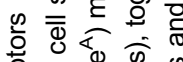

ه

ब

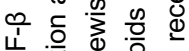

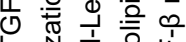

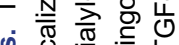

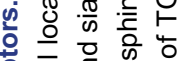

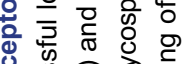

d्ञ

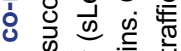

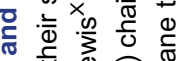

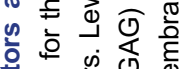

흉 흉

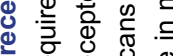

0 ఏ 仓

니 के 항

㟧宁嵌

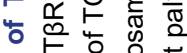

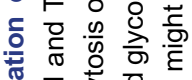

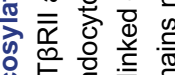

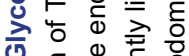

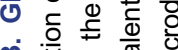

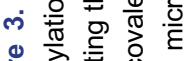

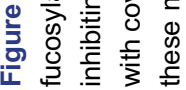


Table 1. Glycosylation of TGF- $\beta$ signaling components

\begin{tabular}{|c|c|c|c|c|c|c|}
\hline \multicolumn{2}{|c|}{$\begin{array}{l}\text { Regulated signaling } \\
\text { components }\end{array}$} & \multirow{2}{*}{$\begin{array}{l}\text { Glycan motif } \\
\text { Oligomannosidic }\end{array}$} & \multirow{3}{*}{$\begin{array}{l}\text { Glycan } \\
\text { type } \\
N \text {-linked }\end{array}$} & \multirow[t]{3}{*}{ Enzyme activity } & \multirow[t]{3}{*}{$\begin{array}{l}\text { Gene } \\
\text { name }\end{array}$} & \multirow{3}{*}{$\begin{array}{l}\text { References } \\
\text { (Miyazono and } \\
\text { Heldin, 1989; } \\
\text { Miyazono et al., } \\
\text { 1992) }\end{array}$} \\
\hline TGF- $\beta$ & LAP & & & & & \\
\hline $\begin{array}{l}\text { secretion } \\
\text { complexes }\end{array}$ & & Complex structure & & & & \\
\hline & LTBP & $N$-glycans & $N$-linked & & & $\begin{array}{l}\text { (Hubmacher and } \\
\text { Reinhardt, } \\
\text { 2009) }\end{array}$ \\
\hline \multirow{8}{*}{$\begin{array}{l}\text { TGF- } \beta \\
\text { receptors }\end{array}$} & \multirow[t]{4}{*}{$T \beta R I / I I$} & Oligomannosidic & $N$-linked & & & (Kim et al., 2012) \\
\hline & & Core fucose & $N$-linked & $\begin{array}{l}\alpha 1,6 \text { fucosyltransferase } \\
8\end{array}$ & FUT8 & $\begin{array}{l}\text { (Wang et al., } \\
\text { 2005; Lin et al., } \\
\text { 2011) }\end{array}$ \\
\hline & & $\beta 1,6$ branch & $N$-linked & $\begin{array}{l}\mathrm{N} \text {-acetylglucosaminyl } \\
\text {-transferase } \mathrm{V}\end{array}$ & MGAT5 & $\begin{array}{l}\text { (Partridge et al., } \\
\text { 2004) }\end{array}$ \\
\hline & & GM3 & glycolipid & $\begin{array}{l}\alpha 2,3 \text { sialytransferase } 5 \\
\text { GM3 synthase }\end{array}$ & ST3GAL5 & (Kim et al., 2013) \\
\hline & T $\beta R I I$ & Sialylation & $\begin{array}{l}\text { Both } N- \\
\text { and } O- \\
\text { linked }\end{array}$ & & & $\begin{array}{l}\text { (Lee et al., 2013; } \\
\text { Lee et al., } \\
\text { 2015) }\end{array}$ \\
\hline & \multirow[t]{3}{*}{$\mathrm{T} \beta \mathrm{RI}$} & Sialyl-Lewis ${ }^{A}$ & $\begin{array}{l}\text { Both } N- \\
\text { and } O- \\
\text { linked }\end{array}$ & $\begin{array}{l}\alpha 1,4 \text { fucosyltransferase } \\
3\end{array}$ & FUT3 & $\begin{array}{l}\text { (Hirakawa et al., } \\
\text { 2014) }\end{array}$ \\
\hline & & Sialyl-Lewis ${ }^{X}$ & $\begin{array}{l}\text { Both } N- \\
\text { and } \mathrm{O}- \\
\text { linked }\end{array}$ & $\begin{array}{l}\alpha 1,4 \text { fucosyltransferase } \\
\quad 3,6\end{array}$ & $\begin{array}{l}\text { FUT3, } \\
\text { FUT6 }\end{array}$ & $\begin{array}{l}\text { (Hirakawa et al., } \\
\text { 2014) }\end{array}$ \\
\hline & & Lewis $^{Y}$ & $\begin{array}{l}\text { Both } N- \\
\text { and } \mathrm{O}- \\
\text { linked }\end{array}$ & $\begin{array}{l}\alpha 1,2 \text { fucosyltransferase } \\
4\end{array}$ & FUT4 & (Li et al., 2010) \\
\hline \multirow[t]{4}{*}{$\begin{array}{l}\text { TGF- } \beta \text { Co- } \\
\text { receptors }\end{array}$} & betaglycan & $\begin{array}{l}\text { Heparin/chondroitin } \\
\text { sulfate }\end{array}$ & $\begin{array}{r}\mathrm{HS} / \mathrm{CS} \\
\mathrm{GAG}\end{array}$ & & & $\begin{array}{l}\text { (Lopez-Casillas } \\
\text { et al., 1991; } \\
\text { Jenkins et al., } \\
\text { 2018) }\end{array}$ \\
\hline & Endoglin & $N$-glycans & $N$-linked & & & $\begin{array}{l}\text { (Lux et al., 2000; } \\
\text { Meurer et al., } \\
\text { 2019) }\end{array}$ \\
\hline & Neuropilin & $N$-glycans & $N$-linked & & & $\begin{array}{l}\text { (Pellet-Many } \\
\text { et al., 2008; Wu } \\
\text { et al., 2017) }\end{array}$ \\
\hline & SMAD2 & O-glycans & O-linked & & & $\begin{array}{l}\text { (Gotoh et al., } \\
2020 \text { ) }\end{array}$ \\
\hline
\end{tabular}

caused by dysregulation of T $\beta R$ II. In contrast, upregulated expression of FUT8 in mice resulted in high levels of core fucosylation of TGF- $\beta$ type I and type II receptors, facilitating TGF- $\beta$ binding and promoting downstream TGF- $\beta$ signaling in breast cancer cells (Tu et al., 2017). The activation of these receptors further promoted cell migration and invasion. Branching of $N$-glycans catalyzed by MGAT5 has been studied to promote galectin-3 expression on the cell surface and sensitivity of TGF- $\beta$ signaling (Fig. 3) (Partridge et al., 2004). Elongation of a poly- $N$-acetyllactosamine chain on $\beta 1-6 G I c N A c$ branches via MGAT5 leads to the formation of a poly- $N$-acetyllactosamine structure (Nagae et al., 2018). This specific glycan structure is preferentially recognized by galectin-3, forming complexes between galectin-3 and MGAT5-modified N-glycans (Partridge et al., 2004; Priglinger et al., 2016). Depletion of Mgat5 in mouse hepatic stellate cells downregulated expression of galectin- 3 and inhibited the sensitivity of TGF- $\beta 1$ to TGF- $\beta$ receptors. Treatment of Mgat5 knock down cells with nystatin, which is a chemical endocytosis inhibitor, promoted receptor accumulation in the membrane and rescued the sensitivity to TGF- $\beta 1$. This provided further evidence that galectin-3 


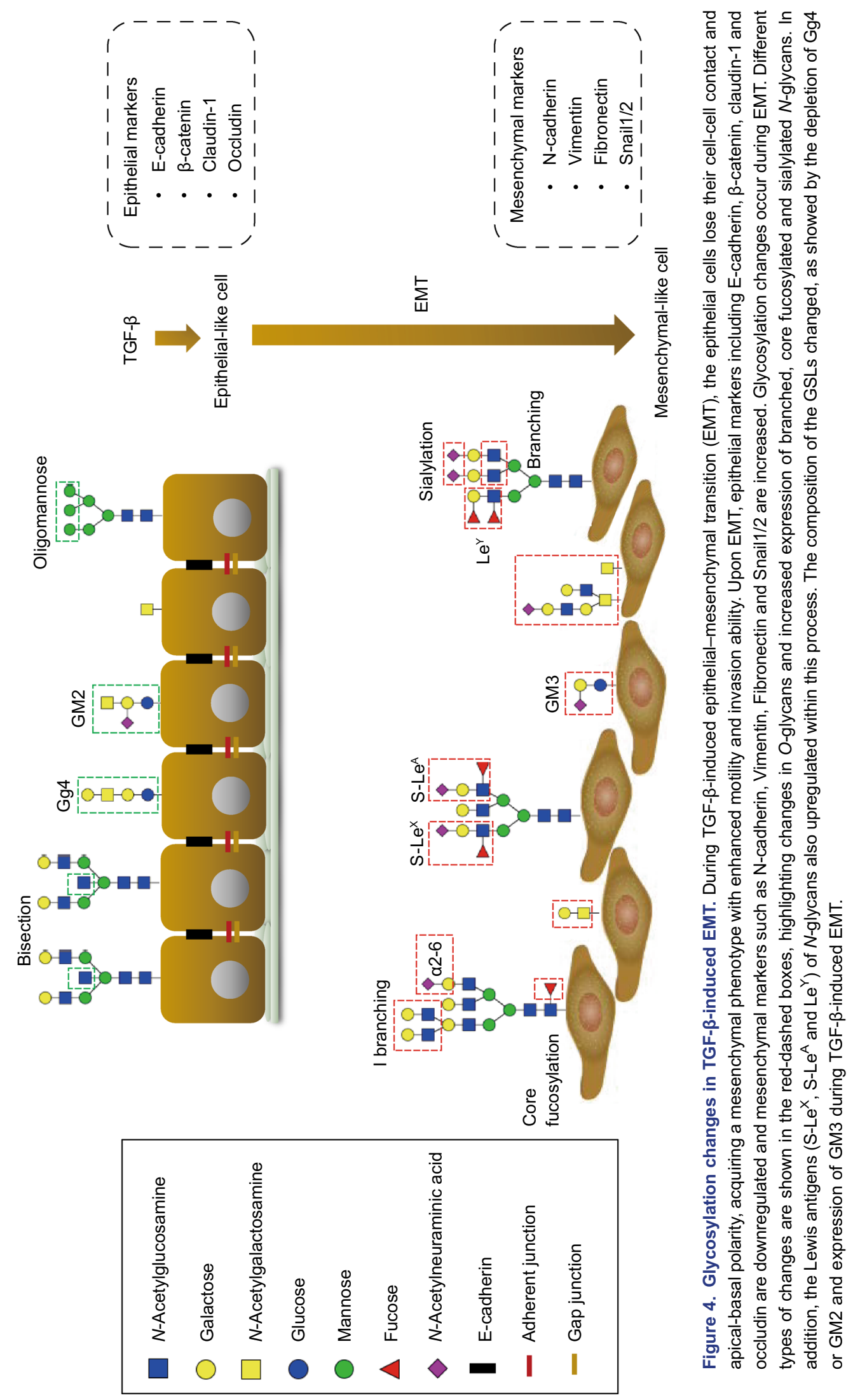


could form a lattice which reinforces TGF- $\beta$ signaling by inhibiting the endocytosis of TGF- $\beta$ receptors (Partridge et al., 2004).

In addition, sialylation has been shown to be associated with TRRII inactivation in colorectal cancer (CRC) cells. Altered sialylation and microsatellite instability (MSI) is a common feature of many malignancies, including CRC (Lee et al., 2013). The MSI phenotype is related to biallelic frameshift mutations in the A10-coding mononucleotide microsatellite of the T $\beta R$ II gene. TRRII displayed biallelic inactivation in the HCT116 CRC cell line. The reconstitution of TRRII signaling in HCT116 cells significantly decreased sialylation of cell surface proteins such as $\beta$-integrin without influencing $\beta$-integrin protein turnover (Lee et al., 2013), which suggests a relationship between sialylation and the classical mutational inactivation of T $\beta R I I$ in CRC cells (Table 1) (Lee et al., 2013; Lee et al., 2015; Ferreira et al., 2018).

FUT3 and FUT6 are involved in the synthesis of Lewis antigens, including the sialyl-Lewis ${ }^{\mathrm{X}}\left(\mathrm{sLe}^{\mathrm{X}}\right)$ and sialyl-Lewis ${ }^{\mathrm{A}}$ $\left(\mathrm{sLe}^{\mathrm{A}}\right)$. Fucosylation of TRRI by FUT3 and FUT6 regulates the activation of the receptors (Fig. 3), leading to CRC cell migration and invasion by EMT (Hirakawa et al., 2014). In addition, highly expressed Lewis $Y\left(\right.$ Le $\left.^{Y}\right)$ is observed in ovarian carcinoma-derived cancers. A detailed study in ovarian carcinoma-derived RMG-I cells showed that TRRI and $T \beta R I I$ had high levels of $\mathrm{Le}^{Y}$ structures which promoted the response of to the TGF- $\beta$-mediated phosphorylation of ERK, AKT and SMAD2/3 (Li et al., 2012). This finding indicates that the modification of TGF- $\beta$ receptors with $\mathrm{Le}^{Y}$ is involved in the regulation of the TGF- $\beta / S M A D$ pathway and in non-SMAD signaling.

\section{Effect of glycosylation on TGF- $\beta$ co-receptor function}

TGF- $\beta$ signaling is initiated by the binding of TGF- $\beta$ to T $\beta R$ I and $T \beta R I I$. In addition to these two classical signaling receptors, betaglycan, endoglin and neuropilins also regulate TGF- $\beta$ signaling as co-receptors (Nickel et al., 2018). Both betaglycan and endoglin are highly glycosylated with $\mathrm{N}$-linked and $\mathrm{O}$-linked glycans, with one difference being that betaglycan has GAG chains that are not found on endoglin (Fig. 3, Table 1) (ten Dijke et al., 2008; Nickel et al., 2018). Betaglycan is a member of the dually modified transmembrane proteoglycan (DMTP) family, the members of which are composed of a core protein with covalently linked heparan sulfated (HS) and/or chondroitin sulfate (CS) GAG chains (Jenkins et al., 2018). Betaglycan is associated with the enhancement of T $\beta R I / S M A D 2 / 3$ signaling (Lopez-Casillas et al., 1991; Esparza-Lopez et al., 2001). In contrast, endoglin is highly expressed on endothelial cells and inhibits T $\beta R I / S M A D 2 / 3$ signaling while promoting activin receptyorlike kinase 1 (ALK1)/SMAD1/5 signaling (Lebrin et al., 2004). Glycosylation changes of betaglycan have been observed during signaling. In osteoblast-like cells, betaglycan binds to basic fibroblast growth factor (bFGF) through its heparan sulfate chains, while binding to TGF- $\beta$ via its core protein. This study suggests that betaglycan might play a physiological role as a bifunctional growth factor-binding protein (Andres et al., 1992). The proper $\mathrm{N}$-glycosylation of endoglin is crucial for directing it to exosomes (Meurer et al., 2019). Defective $\mathrm{N}$-glycosylation of endoglin has been shown to interfere with its membrane localization (Lux et al., 2000). When liver cells were treated with tunicamycin to block the $\mathrm{N}$-glycosylation of endoglin, aberrant trafficking of endoglin was observed.

Neuropilins (NRPs) constitute a family of transmembrane proteins that include NRP1 and NRP2, in which NRP1 undergoes $N$-linked glycosylation (Table 1) (Pellet-Many et al., 2008). Both of these neuropilins play roles as coreceptors in multiple cellular signaling cascades (Guo and Vander Kooi, 2015). NRP1 can capture and activate TGF- $\beta$ by acting as a high-affinity co-receptor for both the latent and active forms of TGF- $\beta 1$ (Glinka and Prud'homme, 2008; Glinka et al., 2011). In fibrotic livers and activated hepatic stellate cells (HSCs), galectin-1 (Gal-1) and its bound proteins could recognize the $\mathrm{N}$-glycans on NRP1. This glycosylation-dependent Gal-1/NRP1 interaction activated the formation of the NRP1/T $\beta$ RII complex and induced the TGF$\beta$-like signaling pathway to promote HSC migration in the absence of TGF- $\beta$ (Wu et al., 2017).

\section{Effect of glycosylation on SMAD protein function}

SMAD2 is a crucial component of TGF- $\beta$ intracellular signaling. A recently published study showed that SMAD2 can be glycosylated by O-GIcNAc and O-GalNAc glycans at the site of Ser110 in the MH1 domain in MCF7 breast cancer cell line (Table 1) (Gotoh et al., 2020). Mutation of Ser110 to alanine in SMAD2 attenuates of its translocation into the nucleus in response to TGF- $\beta$ stimulation. The SMAD2 glycosylation is neither dependent on the C-terminal phosphorylation of SMAD2 nor affected by TGF- $\beta 1$ treatment of the cells. Of note, when MCF7 cells were treated with $17 \beta$ estradiol for more than 6 hours, an inhibition of SMAD2 glycosylation was observed (Gotoh et al., 2020).

\section{GLYCOSYLATION CHANGES IN TGF- $\beta$-INDUCED EMT}

TGF-ß-induced EMT is a key step for cancer cell invasion and metastasis and is accompanied by the aberrant expression of certain glycosyltransferases. The latter results in varying expression levels of glycolipids and cell-surface glycoproteins and contributes to the development of cancer (Lange et al., 2014). Analysis of the glycome and mRNA transcriptional profiles before and after stimulation of (normal and cancer) cells by TGF- $\beta$ in several EMT models revealed upregulation or downregulation of specific glycan structures and glycogenes involved in biosynthesis of $\mathrm{N}$-glycans, $\mathrm{O}-$ glycans and GSL-linked glycans (Fig. 4) (Li et al., 2016). The 
Table 2. Glycosylation changes during TGF- $\beta$ induced EMT

\begin{tabular}{|c|c|c|c|c|c|c|}
\hline \multirow[t]{2}{*}{ Glycan type } & \multirow[t]{2}{*}{ Cell type } & \multicolumn{3}{|c|}{ Altered glycan or glycan-related gene } & \multirow[t]{2}{*}{ Resulted phenotype } & \multirow[t]{2}{*}{ Reference } \\
\hline & & Glycan & Gene & $\begin{array}{l}\text { Promotion } \\
\text { /inhibition }\end{array}$ & & \\
\hline \multirow[t]{5}{*}{$N$-glycan } & $\begin{array}{l}\text { Human breast } \\
\text { cancer cell line, } \\
\text { Mouse mammary } \\
\text { epithelial cells }\end{array}$ & $\begin{array}{l}\text { a2,6-sialic } \\
\text { acid linked } \\
N \text {-glycans } \uparrow\end{array}$ & $\underset{\uparrow}{S T 6 G A L 1}$ & Promotion & $\begin{array}{l}\text { Enhanced cell } \\
\text { migration/invasion }\end{array}$ & (Lu et al., 2014) \\
\hline & $\begin{array}{l}\text { Non-tumorigenic } \\
\text { mouse } \\
\text { hepatocyte } \\
\text { cells, } \\
\text { Murine tumor } \\
\text { cells }\end{array}$ & $\begin{array}{l}\beta 1,6 \\
\text { branching } \\
N \text {-glycans } \uparrow\end{array}$ & MAGT5 $\uparrow$ & Promotion & $\begin{array}{l}\text { Enhanced cell } \\
\text { migration/invasion }\end{array}$ & $\begin{array}{l}\text { (Kamada et al., } \\
\text { 2012; Xu } \\
\text { et al., 2012b) }\end{array}$ \\
\hline & $\begin{array}{l}\text { Human breast } \\
\text { cancer cell line, } \\
\text { Mouse mammary } \\
\text { epithelial cells }\end{array}$ & $\begin{array}{l}\text { Bisecting } \\
N \text {-glycans } \downarrow\end{array}$ & MGAT3 $\downarrow$ & Inhibition & Reduced cell motility & $\begin{array}{l}\text { (Xu et al., } \\
2012 b)\end{array}$ \\
\hline & \multirow{2}{*}{$\begin{array}{l}\text { Human renal } \\
\text { epithelial cells, } \\
\text { Human giant } \\
\text { lung carcinoma } \\
\text { cells }\end{array}$} & \multirow{2}{*}{$\begin{array}{l}\text { Core } \\
\text { fucosylation } \\
\uparrow\end{array}$} & \multirow[t]{2}{*}{ FUT8 $\uparrow$} & \multirow[t]{2}{*}{ Promotion } & $\begin{array}{l}\text { Enhanced cell } \\
\text { migration/invasion }\end{array}$ & (Lin et al., 2011) \\
\hline & & & & & $\begin{array}{l}\text { Development of an } \\
\text { emphysema-like } \\
\text { phenotype }\end{array}$ & $\begin{array}{l}\text { (Wang et al., } \\
\text { 2005) }\end{array}$ \\
\hline \multirow[t]{2}{*}{ O-glycan } & $\begin{array}{l}\text { Human breast } \\
\text { cancer cell line }\end{array}$ & & $\underset{\uparrow}{\text { GALNT14 }}$ & Promotion & \multirow[t]{2}{*}{$\begin{array}{l}\text { Enhanced cell } \\
\text { migration/invasion }\end{array}$} & $\begin{array}{l}\text { (Huanna et al., } \\
\text { 2015) }\end{array}$ \\
\hline & $\begin{array}{l}\text { Human prostate } \\
\text { epithelial cell } \\
\text { line }\end{array}$ & & $\begin{array}{l}\text { GALNT3 } \uparrow \\
\text { GALNT6 } \\
\uparrow\end{array}$ & Promotion & & $\begin{array}{l}\text { (Ding et al., } \\
\text { 2012) }\end{array}$ \\
\hline \multirow[t]{3}{*}{ Glycosphingolipids } & $\begin{array}{l}\text { Human and } \\
\text { mouse breast } \\
\text { epithelial cell }\end{array}$ & GM2, Gg4 $\downarrow$ & $\beta 3 G a l T 4 \downarrow$ & Inhibition & Reduced cell motility & $\begin{array}{l}\text { (Guan et al., } \\
\text { 2009) }\end{array}$ \\
\hline & $\begin{array}{l}\text { Human lens } \\
\text { epithelial cells }\end{array}$ & GM3 $\uparrow$ & & Promotion & $\begin{array}{l}\text { Enhanced cell } \\
\text { migration }\end{array}$ & $\begin{array}{l}\text { (Kim et al., } \\
2013)\end{array}$ \\
\hline & $\begin{array}{l}\text { Human } \\
\text { mammary } \\
\text { epithelial cells }\end{array}$ & GD2 $\downarrow$ & & Inhibition & Inhibited metastasis & $\begin{array}{l}\text { (Sarkar et al., } \\
\text { 2015) }\end{array}$ \\
\hline \multirow[t]{5}{*}{$\begin{array}{l}\text { Other structure } \\
\text { motifs }\end{array}$} & \multirow{2}{*}{$\begin{array}{l}\text { Human } \\
\text { colorectal } \\
\text { cancer cell line }\end{array}$} & $\underset{\uparrow}{\text { Sialyl-Lewis }}{ }^{\mathrm{A}}$ & FUT3 $\uparrow$ & \multirow[t]{2}{*}{ Promotion } & \multirow[t]{2}{*}{$\begin{array}{l}\text { Enhanced cell } \\
\text { migration/invasion }\end{array}$} & \multirow[t]{2}{*}{$\begin{array}{l}\text { (Hirakawa et al., } \\
\text { 2014) }\end{array}$} \\
\hline & & $\underset{\uparrow}{\text { Sialyl-Lewis }}{ }^{\mathrm{X}}$ & FUT6 $\uparrow$ & & & \\
\hline & $\begin{array}{l}\text { Human ovarian } \\
\text { cancer cell line }\end{array}$ & Lewis $^{Y} \uparrow$ & FUT4 $\uparrow$ & Promotion & $\begin{array}{l}\text { Enhanced cell } \\
\text { migration/invasion }\end{array}$ & (Li et al., 2010) \\
\hline & $\begin{array}{l}\text { Human } \\
\text { keratinocyte } \\
\text { cells }\end{array}$ & $\begin{array}{l}\text { Sialylated } \\
N \text {-glycan } \uparrow\end{array}$ & & Promotion & $\begin{array}{l}\text { Enhanced cell } \\
\text { migration/invasion }\end{array}$ & (Du et al., 2015) \\
\hline & $\begin{array}{l}\text { Human breast } \\
\text { cancer cell line }\end{array}$ & I antigen $\uparrow$ & GCNT2 $\uparrow$ & Promotion & $\begin{array}{l}\text { Enhanced cell } \\
\text { migration/invasion/ } \\
\text { lung metastasis }\end{array}$ & $\begin{array}{l}\text { (Zhang et al., } \\
\text { 2011) }\end{array}$ \\
\hline
\end{tabular}

results from all these studies indicate the importance of the cellular glycosylation pattern in both the EMT process and the maintenance of the mesenchymal state.

\section{Role of $\mathbf{N}$-glycans in TGF- $\beta$-induced EMT}

$N$-glycosylation has been demonstrated to be involved in TGF- $\beta$-induced EMT, including branching, bisection, core fucosylation and sialylation (Fig. 4, Table 2). Consequently, the activity of MGAT5 promotes TGF- $\beta$-induced EMT via the retention of T $\beta R \mathrm{I} / \mathrm{II}$ at the cell surface (Partridge et al., 2004). Inhibition of MGAT5 expression, which blocks the generation of branched $N$-glycans, profoundly suppressed TGF- $\beta$-induced EMT mediated by binding of galectin-3 to MGAT5modified $N$-glycans in hepatocytes and prevented liver 
fibrosis. The target glycans are found on TGF- $\beta$ receptors and delay ligand-induced T $\beta R \mathrm{R} / \mathrm{II}$ internalization and further inhibit TGF- $\beta$ signaling (Partridge et al., 2004). In the MKN45 gastric cell line in which MGAT5 was overexpressed, there was an impairment of cell-cell interactions and reduced contact inhibition. MGAT5-knockout cells retained an epithelial morphology, as characterized by the high expression levels of E-cadherin (Pinho et al., 2009; Pinho et al., 2013). Conversely, MGAT3 catalyzes the addition of bisecting GlcNAc and competes with MGAT5, resulting in an increased number of bisected structures and decreased branching. MGAT3 overexpression inhibited TGF- $\beta$-induced cell motility and the EMT in a human breast cancer MCF10A cell line and the GE11 mouse cell line (Xu et al., 2012b). A further study reported that MGAT3 induced a delay in the turnover rate of E-cadherin making it more stable on the cell membrane. The latter contributes to the formation of adherens junctions, thereby preventing clathrin-dependent E-cadherin endocytosis, and may play a role in tumor suppression (Pinho et al., 2009).

Core fucosylation of $\mathrm{N}$-glycans shows an essential role in activation of TGF- $\beta$ signaling. In human renal proximal tubular epithelial cells, blocking the expression of FUT8 for core fucosylation caused the inactivation of TGF-B/SMAD2/3 signaling and resulted in the attenuation of the EMT (Lin et al., 2011). Terminal $\alpha 2,6$-sialylation significantly increased during TGF- $\beta$-induced EMT in the GE11 murine epithelial cell line (Lu et al., 2014). This outcome was demonstrated by the increased expression of $\beta$-galactoside $\alpha 2,6$-sialyltransferase 1 (ST6GAL1) during TGF- $\beta$-induced EMT, which catalyzes the addition of terminal $\alpha 2,6$-sialic acid linkages on galactose (Fig. 4). Overexpression of St6gal1 promoted the induction of the mesenchymal marker $\alpha$-smooth muscle actin ( $\alpha-S M A)$ and accelerated the EMT process. In contrast, knocking down St6gal1 in the GE11 cell line inhibited the TGF- $\beta$-induced EMT and upregulated the epithelial marker E-cadherin. This effect was also observed in the MDA-MB-231 human breast cancer cells, and the mesenchymal phenotype of this cell line was partially reversed upon ST6GAL1 knockdown, as determined by an increase in the epithelial marker E-cadherin and a decrease in mesenchymal markers, including $\alpha-S M A, \beta 1$ integrin and fibronectin (FN) (Lu et al., 2014).

\section{Role of O-glycans in TGF- $\beta$-induced EMT}

Numerous studies indicate that structural changes in mucin type O-glycosylation could induce EMT and promote cancer cell invasiveness and metastasis (Gu et al., 2010; Mi et al., 2011; Lynch et al., 2012). Mucin-type O-glycosylation is catalyzed by enzymes in the $N$-acetylgalactosaminyltransferase (GALNT) family, including GALNT14. Clinical data have shown that GALNT14 is highly expressed in various human cancers, such as breast cancer (Huanna et al., 2015) and hepatocellular carcinoma (Lin et al., 2014), and plays an important role in regulating malignant characteristics, as is exemplified by an increased expression of some mesenchymal markers $\mathrm{N}$-cadherin and vimentin and TGF- $\beta$ (Table 2) (Huanna et al., 2015). Mucin type O-glycosylation is also plays an important role in TGF- $\beta$-induced EMT in human prostate epithelial cell lines by regulating the reactivity of oncofetal fibronectin (onfFN) (Freire-de-Lima et al., 2011). In fetal cells and cancer tissues, there is a significant increase in onfFN upon treatment with TGF- $\beta$. The reactivity of onfFN requires the addition of an O-glycan at a specific Thr, catalyzed by GALNT3, and/or GALNT6 (Freire-de-Lima et al., 2011; Ventura et al., 2018). When both GALNT3 and GALNT6 of onfFN are depleted from cells, the TGF- $\beta$-induced EMT process is blunted. Further investigation showed that only O-glycosylated onfFN, and not FN lacking O-GalNAc, can promote TGF- $\beta$-induced EMT (Table 2) (Ding et al., 2012). Although the molecular mechanism of this unusual glycan-modified FN-promoted EMT is unclear, this O-glycosylated onfFN might be a potential target for cancer therapy.

\section{Role of glycosphingolipids in TGF- $\beta$-induced EMT}

The inhibition of GSLs in the TGF- $\beta$-induced EMT process has been reported in normal murine NMuMG mammary gland cells and human MCF7 mammary carcinoma cells. During the TGF- $\beta$-induced EMT process, the composition of the GSLs changed in these cell lines: in NMuMG cells, Gg4 or GM2 was depleted or decreased (Guan et al., 2009), and in HCV29 cells, GM2 was decreased (Fig. 4, Table 2) (Guan et al., 2009). The use of the GlcCer synthase inhibitor D-threo-1-(3',4'-ethylenedioxy)-phenyl-2-palmitoylamino-3pyrrolidino-1-propanol (EtDO-P4) to inhibit the synthesis of GSLs led to upregulated mesenchymal markers, including $\mathrm{N}$-cadherin, vimentin and fibronectin, and promotion of cell motility. The enhanced EMT by GSL depletion or TGF- $\beta$ induced EMT can be abrogated by the addition of exogenous GM2 and Gg4. In addition, blocking the expression of GD3, which is a ganglioside involved in GD2 biosynthesis, initiates the EMT process, and the mesenchymal phenotype is maintained (Sarkar et al., 2015). Inhibition of another ganglioside, GM3, by the inhibitor d-threo-1-phenyl-2-decanoylamino-3-morpholino-1-propanol (d-PDMP) or by knocking it down led to mitigated cell motility and blocked TGF- $\beta$-induced EMT through a potential interaction with TßRs (Kim et al., 2013). In contrast, elevated levels of ganglioside GM3 positively regulates cell migration and TGF- $\beta$-induced EMT in lens epithelial cells.

\section{Role of other glycan epitopes/terminal structures in TGF- $\beta$-induced EMT}

Sialic acids, a family of nine-carbon backbone monosaccharides, are usually overexpressed in cancer cells to protect malignant cells from the cytotoxic effect of natural killer cells (Chen and Varki, 2010; Chaudhary et al., 2019). Du et al. used a chemical reporter strategy and visualized the 
dynamic changes in sialylation during TGF- $\beta$-induced modulation of epithelial plasticity in human keratinocyte $\mathrm{HaCaT}$ cells. Using 3Fax-Neu5Ac, a global inhibitor of sialylation, the EMT process was promoted in the early stage, and once the cells entered the mesenchymal-like state, the effect was no longer significant (Du et al., 2015). Moreover, upregulation of I-branching $\beta-1,6-N$-acetylglucosaminyl transferase 2 (GCNT2) has been observed in TGF- $\beta$-induced EMT in basal-like breast tumors and were correlated with metastasis phenotypes (Table 2) (Zhang et al., 2011). This enzyme is a member of the $\beta-1,6-N$-acetylglucosaminyltransferase family and is involved in driving the progression of breast tumors and malignancies (Zhang et al., 2011). Overexpression of GCNT2 promoted TGF- $\beta$-induced EMT, which was accompanied by enhanced breast cancer cell migration, invasion and lung metastasis (Andergassen et al., 2015). Knocking down GCNT2 showed the opposite regulatory effect on these EMT-related cellular processes.

\section{CONCLUSION}

In this review, we described evidence showing the role of specific $N$-glycans, O-glycans, and GSLs in TGF- $\beta$ signaling and glycosylation changes during the TGF- $\beta$-induced EMT. Several studies have recently demonstrated that $N$-glycosylation of T $\beta R$ II can regulate TGF- $\beta$ signaling by remodeling TGF- $\beta$ receptors and inhibiting endocytosis. The EMT process is accompanied by changes in glycosylation, such as an increase in sialylation and the number of $\mathrm{sLe}^{\mathrm{X}}$ and $\mathrm{sLe}^{\mathrm{A}}$ structures. However, in most cases, the molecular mechanisms and clinical significance of specific glycosylation changes during EMT are still unclear.

Many studies have contributed to the current knowledge of glycosylation of cells in TGF- $\beta$ signaling. To determine the activity of glycosyltransferases and glycosidases in vitro, researchers have developed, and continue to improve, chromatographic, radiochemical or spectrophotometric techniques to follow the loss of substrates or the formation of the reaction products (Laughlin and Bertozzi, 2009; van Kooyk et al., 2013; Alteen et al., 2020). The lectin microarray (Zhang et al., 2016) and mass spectrometry (Couto et al., 2018; Gargano et al., 2020) are used to check glycosylation profiles and to discover new glycan structures. These data need to be integrated with genomics and proteomic profiling studies that determine the changes in expression and localization of glycosyltransferases and glycosidases and link them to biological responses. It will be further important that these studies are complemented with functional studies in which the effect of misexpression of specific genes encoding for glycan modifying enzymes and their substrates. Moreover, the effect of cellular responses upon treatment with pharmacological small molecule inhibitors of glycan modifying enzymes or (if possible) the addition of glycan substrates or products on cellular responses will be infor- mative. The technological advances and holistic approach to identify and functionally investigate changes in glycosylation, will help in the identification of new glycan markers and create inroads for the development of better diagnosis and improved therapies for cancer patients.

\section{ACKNOWLEDGMENTS}

We acknowledge the support of the Chinese Scholarship Council (CSC) to J.Z. and Cancer Genomics Centre Netherlands (CGC. NL) to P.t.D.

\section{AUTHOR CONTRIBUTIONS}

JZ., writing of the original draft and figure preparation; T.Z., figure preparation, revision and editing; and M.W. and P.t.D., revision and editing.

\section{ABBREVIATIONS}

AFP, alpha-fetoprotein; ALK, activin receptor-like kinase; Asn, asparagine; C1GALT1, core 1 1,3-galactosyltransferase; CA125, cancer antigen 125; CA19-9, carbohydrate antigen 19-9; CEA, carcinoembryonic antigen; CRCs, colorectal cancers; CS, chondroitin sulfate; DMTPs, dually modified transmembrane proteoglycans; $d$-PDMP, $d$-threo-1-phenyl-2-decanoylamino-3-morpholino-1propanol; E-cadherin, epithelial cadherin; ECM, extracellular matrix; EGF, epidermal growth factor; EMP, epithelial-mesenchymal plasticity; EMT, epithelial-to-mesenchymal transition; EtDO-P4, D-threo1-(3',4'-ethylenedioxy)-phenyl-2-palmitoylamino -3-pyrrolidino-1-propanol; FGF, basic fibroblast growth factor; FN, fibronectin; FUT, fucosyltransferase; GAG, glycosaminoglycan; Gal-1, galectin-1; GalCer, galactosylceramides; GALNT, $N$-acetylgalactosaminyl transferase; GCNT2, I-branching-1,6- $N$-acetylglucosaminyl transferase 2; GlcCer, glucosylceramides; GPC1, glypican-1GS, Glycine-Serinerich; GSLs, glycosphingolipids; GTs, glycosyltransferases; HCC, hepatocellular carcinoma; HGF, hepatocyte growth factor; HS, heparan sulfate; HSC, hepatic stellate cells; LAP, latency-associated peptide; Le ${ }^{Y}$, Lewis Y; LTBP, latent TGF- $\beta$-binding protein; $\operatorname{Man}_{3^{-}}$

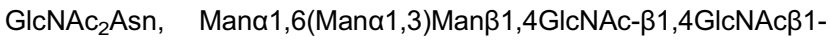
Asn; MGAT5, $N$-acetylglucosaminyl-transferase $\mathrm{V}$; MMPs, matrix metalloproteinases; $\mathrm{MSI}$, microsatellite instability; $\mathrm{N}$-glycans, $\mathrm{N}$ linked glycans; NRPs, neuropilins; O-GalNAc, O-linked alpha- $N$ acetylgalactosamine; O-GIcNAc, O-linked $\beta$ - $N$-acetylglucosamine; O-glycans, O-linked glycans; OnfFN, oncofetal fibronectin; PDAC, pancreatic ductal adenocarcinoma; PDGF, platelet-derived growth factor; PGs, proteoglycans; PSA, prostate specific antigen; R-SMADs, receptor-specific SMADs; Ser, Serine; $s L e^{A}$, sialylLewis $^{A}$; sLe ${ }^{X}$, sialyl-Lewis ${ }^{X}$; SMAD, Sma and Mad related protein; ST6GAL1, $\beta$-galactoside $\alpha-2,6$-sialyltranferase 1 ; T antigens, tumor antigens; T $\beta R I$, TGF- $\beta$ type I receptor; T $\beta R I I, T G F-\beta$ type II receptor; TGF- $\beta$, transforming growth factor- $\beta$; Thr, Threonine; Trp, Tryptophan; VEGF, vascular endothelial growth factor; ZEB, zinc finger E-box-binding homeobox; ZO-1, zona occludens protein-1; ZP-1, zona pellucida-1; $\alpha$-SMA, alpha-smooth muscle actin; $\beta 1,6 \mathrm{GICNAc}$, $\beta 1,6-\mathrm{N}$-acetylglucosamine 


\section{COMPLIANCE WITH ETHICS GUIDELINES}

Jing Zhang, Peter ten Dijke, Manfred Wuhrer and Tao Zhang declare that they have no conflict of interest. This article does not contain any studies with human or animal subjects performed by the any of the authors.

\section{OPEN ACCESS}

This article is licensed under a Creative Commons Attribution 4.0 International License, which permits use, sharing, adaptation, distribution and reproduction in any medium or format, as long as you give appropriate credit to the original author(s) and the source, provide a link to the Creative Commons licence, and indicate if changes were made. The images or other third party material in this article are included in the article's Creative Commons licence, unless indicated otherwise in a credit line to the material. If material is not included in the article's Creative Commons licence and your intended use is not permitted by statutory regulation or exceeds the permitted use, you will need to obtain permission directly from the copyright holder. To view a copy of this licence, visit http:// creativecommons.org/licenses/by/4.0/.

\section{REFERENCES}

Albertsen PC (2018) Prostate cancer screening with prostatespecific antigen: where are we going? Cancer 124:453-455

Alteen MG, Gros C, Meek RW, Cardoso DA, Busmann JA, Sangouard G, Deen MC, Tan HY, Shen DL, Russell CC et al (2020) A direct fluorescent activity assay for glycosyltransferases enables convenient high-throughput screening: application to O-GlcNAc transferase. Angew Chem Int Ed Engl 59:1-11

Andergassen U, Liesche F, Kolbl AC, Ilmer M, Hutter S, Friese K, Jeschke $U$ (2015) Glycosyltransferases as markers for early tumorigenesis. Biomed Res Int 2015(792672):1-11

Andres JL, DeFalcis D, Noda M, Massague J (1992) Binding of two growth factor families to separate domains of the proteoglycan betaglycan. J Biol Chem 267:5927-5930

Auclin E, Andre T, Taieb J, Benetkiewicz M, de Gramont A, Vernerey D (2018) Low-level postoperative carcinoembryonic antigen improves survival outcomes stratification in patients with stage II colon cancer treated with standard adjuvant treatments. Eur J Cancer 97:55-56

Ballehaninna UK, Chamberlain RS (2012) The clinical utility of serum CA 19-9 in the diagnosis, prognosis and management of pancreatic adenocarcinoma: an evidence based appraisal. J Gastrointest Oncol 3:105-119

Bassaganas S, Carvalho S, Dias AM, Perez-Garay M, Ortiz MR, Figueras J, Reis CA, Pinho SS, Peracaula R (2014) Pancreatic cancer cell glycosylation regulates cell adhesion and invasion through the modulation of $\alpha 2 \beta 1$ integrin and E-cadherin function. PLoS ONE 9(e98595):1-14

Batlle E, Massague J (2019) Transforming growth factor- $\beta$ signaling in immunity and cancer. Immunity 50:924-940

Boscher C, Dennis JW, Nabi IR (2011) Glycosylation, galectins and cellular signaling. Curr Opin Cell Biol 23:383-392
Breimer ME, Saljo K, Barone A, Teneberg S (2017) Glycosphingolipids of human embryonic stem cells. Glycoconj J 34:713-723

Brockhausen I, Stanley P (2015) O-GalNAc glycans. In: Varki A, Cummings RD, Esko JD, Stanley P, Hart GW, Aebi M, Darvill AG, Kinoshita T, Packer NH et al (eds) Essentials of glycobiology, 3rd edn. Cold Spring Harbor, New York, pp 113-123

Brunner AM, Lioubin MN, Marquardt H, Malacko AR, Wang WC, Shapiro RA, Neubauer M, Cook J, Madisen L, Purchio AF (1992) Site-directed mutagenesis of glycosylation sites in the transforming growth factor-beta 1 (TGF $\beta 1$ ) and TGF $\beta 2$ (414) precursors and of cysteine residues within mature TGF $\beta 1$ : effects on secretion and bioactivity. Mol Endocrinol 6:1691-1700

Budi EH, Duan D, Derynck R (2017) Transforming growth factor- $\beta$ receptors and smads: regulatory complexity and functional versatility. Trends Cell Biol 27:658-672

Chaudhary PM, Toraskar S, Yadav R, Hande A, Yellin RA, Kikkeri R (2019) Multivalent sialosides: a tool to explore the role of sialic acids in biological processes. Chem Asian J 14:1344-1355

Chen X, Varki A (2010) Advances in the biology and chemistry of sialic acids. ACS Chem Biol 5:163-176

Cheng J, Wang W, Zhang Y, Liu X, Li M, Wu Z, Liu Z, Lv Y, Wang B (2014) Prognostic role of pre-treatment serum AFP-L3\% in hepatocellular carcinoma: systematic review and meta-analysis. PLoS ONE 9(e87011):1-8

Colak S, Ten Dijke P (2017) Targeting TGF- $\beta$ signaling in cancer. Trends Cancer 3:56-71

Couto N, Davlyatova L, Evans CA, Wright PC (2018) Application of the broadband collision-induced dissociation (bbCID) mass spectrometry approach for protein glycosylation and phosphorylation analysis. Rapid Commun Mass Spectrom 32:75-85

D’Angelo G, Capasso S, Sticco L, Russo D (2013) Glycosphingolipids: synthesis and functions. FEBS J 280:6338-6353

Dennis JW, Nabi IR, Demetriou M (2009) Metabolism, cell surface organization, and disease. Cell 139:1229-1241

Derynck R, Muthusamy BP, Saeteurn KY (2014) Signaling pathway cooperation in TGF- $\beta$-induced epithelial-mesenchymal transition. Curr Opin Cell Biol 31:56-66

Derynck R, Weinberg RA (2019) EMT and cancer: more than meets the eye. Dev Cell 49:313-316

Ding Y, Gelfenbeyn K, Freire-de-Lima L, Handa K, Hakomori SI (2012) Induction of epithelial-mesenchymal transition with O-glycosylated oncofetal fibronectin. FEBS Lett 586:1813-1820

Dochez V, Caillon H, Vaucel E, Dimet J, Winer N, Ducarme G (2019) Biomarkers and algorithms for diagnosis of ovarian cancer: CA125, HE4, RMI and ROMA, a review. J Ovarian Res 12(28):19

Dong X, Hudson NE, Lu C, Springer TA (2014) Structural determinants of integrin $\beta$-subunit specificity for latent TGF- $\beta$. Nat Struct Mol Biol 21:1091-1096

Du J, Hong S, Dong L, Cheng B, Lin L, Zhao B, Chen YG, Chen X (2015) Dynamic sialylation in transforming growth factor-beta (TGF- $\beta$ )-induced epithelial to mesenchymal transition. J Biol Chem 290:12000-12013

Dube DH, Bertozzi CR (2005) Glycans in cancer and inflammationpotential for therapeutics and diagnostics. Nat Rev Drug Discov 4:477-488 
Esparza-Lopez J, Montiel JL, Vilchis-Landeros MM, Okadome T, Miyazono K, Lopez-Casillas F (2001) Ligand binding and functional properties of betaglycan, a co-receptor of the transforming growth factor- $\beta$ superfamily. Specialized binding regions for transforming growth factor- $\beta$ and inhibin $A$. J Biol Chem 276:14588-14596

Ferreira IG, Pucci M, Venturi G, Malagolini N, Chiricolo M, Dall'Olio F (2018) Glycosylation as a main regulator of growth and death factor receptors signaling. Int J Mol Sci 19:1-28

Freire-de-Lima L (2014) Sweet and sour: the impact of differential glycosylation in cancer cells undergoing epithelial-mesenchymal transition. Front Oncol 4(59):1-10

Freire-de-Lima L, Gelfenbeyn K, Ding Y, Mandel U, Clausen H, Handa K, Hakomori SI (2011) Involvement of O-glycosylation defining oncofetal fibronectin in epithelial-mesenchymal transition process. Proc Natl Acad Sci USA 108:17690-17695

Furukawa K, Ohmi Y, Ohkawa Y, Bhuiyan RH, Zhang P, Tajima O, Hashimoto N, Hamamura K, Furukawa K (2019) New era of research on cancer-associated glycosphingolipids. Cancer Sci 110:1544-1551

Fuster MM, Esko JD (2005) The sweet and sour of cancer: glycans as novel therapeutic targets. Nat Rev Cancer 5:526-542

Gargano AFG, Schouten O, van Schaick G, Roca LS, van den BergVerleg JH, Haselberg R, Akeroyd M, Abello N, Somsen GW (2020) Profiling of a high mannose-type N-glycosylated lipase using hydrophilic interaction chromatography-mass spectrometry. Anal Chim Acta 1109:69-77

Glinka Y, Prud'homme GJ (2008) Neuropilin-1 is a receptor for transforming growth factor $\beta 1$, activates its latent form, and promotes regulatory $T$ cell activity. J Leukoc Biol 84:302-310

Glinka Y, Stoilova S, Mohammed N, Prud'homme GJ (2011) Neuropilin-1 exerts co-receptor function for TGF- $\beta 1$ on the membrane of cancer cells and enhances responses to both latent and active TGF- $\beta$. Carcinogenesis 32:613-621

Gomes C, Osorio H, Pinto MT, Campos D, Oliveira MJ, Reis CA (2013) Expression of ST3GAL4 leads to SLe(x) expression and induces c-Met activation and an invasive phenotype in gastric carcinoma cells. PLoS One 8(e66737):1-13

Gotoh T, Iwahana H, Kannan S, Marei RG, Mousa H, Elgamal M, Souchelnytskyi S (2020) Glycosylation is a novel TGF 1 1independent post-translational modification of Smad2. Biochem Biophys Res Commun 521:1010-1016

Gu Y, Mi W, Ge Y, Liu H, Fan Q, Han C, Yang J, Han F, Lu X, Yu W (2010) GlcNAcylation plays an essential role in breast cancer metastasis. Cancer Res 70:6344-6351

Guan F, Handa K, Hakomori SI (2009) Specific glycosphingolipids mediate epithelial-to-mesenchymal transition of human and mouse epithelial cell lines. Proc Natl Acad Sci USA 106:74617466

Guo HF, Vander Kooi CW (2015) Neuropilin functions as an essential cell surface receptor. J Biol Chem 290:29120-29126

Haltiwanger RS, Wells L, Freeze HH, Stanley P (2015) Other classes of eukaryotic glycans. In: Varki A, Cummings RD, Esko JD, Stanley P, Hart GW, Aebi M, Darvill AG, Kinoshita T, Packer $\mathrm{NH}$ et al (eds) Essentials of glycobiology, 3rd edn. Springer, New York, pp 151-160
Hanahan D, Weinberg RA (2000) The hallmarks of cancer. Cell 100:57-70

Hanahan D, Weinberg RA (2011) Hallmarks of cancer: the next generation. Cell 144:646-674

Hao Y, Baker D, Ten Dijke P (2019) TGF-ß-mediated epithelialmesenchymal transition and cancer metastasis. Int $\mathrm{J}$ Mol Sci 20:1-34

Heldin CH (2004) Development and possible clinical use of antagonists for PDGF and TGF- $\beta$. Ups J Med Sci 109:165-178

Heldin $\mathrm{CH}$, Miyazono K, ten Dijke P (1997) TGF- $\beta$ signalling from cell membrane to nucleus through SMAD proteins. Nature 390:465-471

Heldin $\mathrm{CH}$, Moustakas A (2016) Signaling receptors for TGF- $\beta$ family members. Cold Spring Harb Perspect Biol 8:1-33

Hill CS (2016) Transcriptional control by the SMADs. Cold Spring Harb Perspect Biol 8:1-17

Hirakawa M, Takimoto R, Tamura F, Yoshida M, Ono M, Murase K, Sato $Y$, Osuga T, Sato T, lyama $S$ et al (2014) Fucosylated TGF- $\beta$ receptors transduces a signal for epithelial-mesenchymal transition in colorectal cancer cells. Br J Cancer 110:156-163

Huanna T, Tao Z, Xiangfei W, Longfei A, Yuanyuan X, Jianhua W, Cuifang Z, Manjing J, Wenjing C, Shaochuan Q et al (2015) GALNT14 mediates tumor invasion and migration in breast cancer cell MCF-7. Mol Carcinog 54:1159-1171

Hubmacher D, Reinhardt DP (2009) One more piece in the fibrillin puzzle. Structure 17:635-636

Hyytiainen M, Penttinen C, Keski-Oja J (2004) Latent TGF- $\beta$ binding proteins: extracellular matrix association and roles in TGF- $\beta$ activation. Crit Rev Clin Lab Sci 41:233-264

lozzo RV, Schaefer L (2015) Proteoglycan form and function: a comprehensive nomenclature of proteoglycans. Matrix Biol 42:11-55

Jenkins LM, Horst B, Lancaster CL, Mythreye K (2018) Dually modified transmembrane proteoglycans in development and disease. Cytokine Growth Factor Rev 39:124-136

Kamada Y, Mori K, Matsumoto H, Kiso S, Yoshida Y, Shinzaki S, Hiramatsu N, Ishii M, Moriwaki K, Kawada N et al (2012) $\mathrm{N}$-Acetylglucosaminyltransferase $\mathrm{V}$ regulates TGF- $\beta$ response in hepatic stellate cells and the progression of steatohepatitis. Glycobiology 22:778-787

Katsuno Y, Lamouille S, Derynck R (2013) TGF- $\beta$ signaling and epithelial-mesenchymal transition in cancer progression. Curr Opin Oncol 25:76-84

Kim SJ, Chung TW, Choi HJ, Kwak CH, Song KH, Suh SJ, Kwon KM, Chang YC, Park YG, Chang HW et al (2013) Ganglioside GM3 participates in the TGF- $\beta 1$-induced epithelial-mesenchymal transition of human lens epithelial cells. Biochem J 449:241-251

Kim YW, Park J, Lee HJ, Lee SY, Kim SJ (2012) TGF- $\beta$ sensitivity is determined by $\mathrm{N}$-linked glycosylation of the type II TGF- $\beta$ receptor. Biochem J 445:403-411

Kirkbride KC, Ray BN, Blobe GC (2005) Cell-surface co-receptors: emerging roles in signaling and human disease. Trends Biochem Sci 30:611-621

Krasnova L, Wong CH (2016) Understanding the chemistry and biology of glycosylation with glycan synthesis. Annu Rev Biochem 85:599-630 
Lamouille S, Connolly E, Smyth JW, Akhurst RJ, Derynck R (2012) TGF- $\beta$-induced activation of mTOR complex 2 drives epithelialmesenchymal transition and cell invasion. J Cell Sci 125:12591273

Lange T, Samatov TR, Tonevitsky AG, Schumacher U (2014) Importance of altered glycoprotein-bound $\mathrm{N}$ - and O-glycans for epithelial-to-mesenchymal transition and adhesion of cancer cells. Carbohydr Res 389:39-45

Lau KS, Partridge EA, Grigorian A, Silvescu Cl, Reinhold VN, Demetriou M, Dennis JW (2007) Complex N-glycan number and degree of branching cooperate to regulate cell proliferation and differentiation. Cell 129:123-134

Laughlin ST, Bertozzi CR (2009) Imaging the glycome. Proc Natl Acad Sci USA 106:12-17

Lebrin F, Goumans MJ, Jonker L, Carvalho RL, Valdimarsdottir G, Thorikay M, Mummery C, Arthur HM, ten Dijke P (2004) Endoglin promotes endothelial cell proliferation and TGF-B/ALK1 signal transduction. EMBO J 23:4018-4028

Lee J, Ballikaya S, Schonig K, Ball CR, Glimm H, Kopitz J, Gebert J (2013) Transforming growth factor $\beta$ receptor 2 (TGFBR2) changes sialylation in the microsatellite unstable (MSI) Colorectal cancer cell line HCT116. PLoS ONE 8(e57074):1-10

Lee J, Warnken U, Schnolzer M, Gebert J, Kopitz J (2015) A new method for detection of tumor driver-dependent changes of protein sialylation in a colon cancer cell line reveals nectin- 3 as TGFBR2 target. Protein Sci 24:1686-1694

Leerapun A, Suravarapu SV, Bida JP, Clark RJ, Sanders EL, Mettler TA, Stadheim LM, Aderca I, Moser CD, Nagorney DM et al (2007) The utility of Lens culinaris agglutinin-reactive alpha-fetoprotein in the diagnosis of hepatocellular carcinoma: evaluation in a United States referral population. Clin Gastroenterol Hepatol 5:394-402

Li F, Lin B, Hao Y, Li Y, Liu J, Cong J, Zhu L, Liu Q, Zhang S (2010) Lewis $Y$ promotes growth and adhesion of ovarian carcinomaderived RMG-I cells by upregulating growth factors. Int J Mol Sci 11:3748-3759

Li FF, Liu JJ, Liu DW, Lin B, Hao YY, Cong JP, Zhu LC, Gao S, Zhang SL, Iwamori M (2012) Lewis $Y$ regulates signaling molecules of the transforming growth factor $\beta$ pathway in ovarian carcinoma-derived RMG-I cells. Int J Oncol 40:1196-1202

Li X, Wang X, Tan Z, Chen S, Guan F (2016) Role of glycans in cancer cells undergoing epithelial-mesenchymal transition. Front Oncol 6(33):1-5

Lin H, Wang D, Wu T, Dong C, Shen N, Sun Y, Sun Y, Xie H, Wang $N$, Shan $L$ (2011) Blocking core fucosylation of TGF- $\beta 1$ receptors downregulates their functions and attenuates the epithelialmesenchymal transition of renal tubular cells. Am J Physiol Renal Physiol 300:F1017-1025

Lin WR, Hsu CW, Chen YC, Chang ML, Liang KH, Huang YH, Yeh CT (2014) GALNT14 genotype, alpha-fetoprotein and therapeutic side effects predict post-chemotherapy survival in patients with advanced hepatocellular carcinoma. Mol Clin Oncol 2:630-640

Lindahl U, Couchman J, Kimata K, Esko JD (2015) Proteoglycans and sulfated glycosaminoglycans. In: Varki A, Cummings RD, Esko JD, Stanley P, Hart GW, Aebi M, Darvill AG, Kinoshita T, Packer $\mathrm{NH}$ et al (eds) Essentials of glycobiology, 3rd edn. Cold Spring Harbor, New York, pp 207-221
Liu CH, Hu RH, Huang MJ, Lai IR, Chen CH, Lai HS, Wu YM, Huang MC (2014a) C1GALT1 promotes invasive phenotypes of hepatocellular carcinoma cells by modulating integrin $\beta 1$ glycosylation and activity. PLoS ONE 9(e94995):1-9

Liu T, Zhang S, Chen J, Jiang K, Zhang Q, Guo K, Liu Y (2014b) The transcriptional profiling of glycogenes associated with hepatocellular carcinoma metastasis. PLoS ONE 9(e107941):1-13

Lopez-Casillas F, Cheifetz S, Doody J, Andres JL, Lane WS, Massague $J$ (1991) Structure and expression of the membrane proteoglycan betaglycan, a component of the TGF- $\beta$ receptor system. Cell 67:785-795

Lopez AR, Cook J, Deininger PL, Derynck R (1992) Dominant negative mutants of transforming growth factor- $\beta 1$ inhibit the secretion of different transforming growth factor-beta isoforms. Mol Cell Biol 12:1674-1679

Lu J, Isaji T, Im S, Fukuda T, Hashii N, Takakura D, Kawasaki N, Gu J (2014) beta-Galactoside alpha2,6-sialyltranferase 1 promotes transforming growth factor- $\beta$-mediated epithelial-mesenchymal transition. J Biol Chem 289:34627-34641

Lu W, Kang Y (2019) Epithelial-mesenchymal plasticity in cancer progression and metastasis. Dev Cell 49:361-374

Luo K (2017) Signaling cross talk between TGF- $\beta /$ Smad and other signaling pathways. Cold Spring Harb Perspect Biol 9:1-28

Lux A, Gallione CJ, Marchuk DA (2000) Expression analysis of endoglin missense and truncation mutations: insights into protein structure and disease mechanisms. Hum Mol Genet 9:745-755

Lynch TP, Ferrer CM, Jackson SR, Shahriari KS, Vosseller K, Reginato MJ (2012) Critical role of O-linked beta-N-acetylglucosamine transferase in prostate cancer invasion, angiogenesis, and metastasis. J Biol Chem 287:11070-11081

Ma J, Hart GW (2014) O-GIcNAc profiling: from proteins to proteomes. Clin Proteomics 11(8):1-16

Marsico G, Russo L, Quondamatteo F, Pandit A (2018) Glycosylation and integrin regulation in cancer. Trends Cancer 4:537-552

Massague J (2000) How cells read TGF- $\beta$ signals. Nat Rev Mol Cell Biol 1:169-178

Massague J (2012) TGF $\beta$ signalling in context. Nat Rev Mol Cell Biol 13:616-630

Matsumoto K, Yokote H, Arao T, Maegawa M, Tanaka K, Fujita Y, Shimizu C, Hanafusa T, Fujiwara Y, Nishio K (2008) N-Glycan fucosylation of epidermal growth factor receptor modulates receptor activity and sensitivity to epidermal growth factor receptor tyrosine kinase inhibitor. Cancer Sci 99:1611-1617

McMahon GA, Dignam JD, Gentry LE (1996) Structural characterization of the latent complex between transforming growth factor $\beta 1$ and $\beta 1$-latency-associated peptide. Biochem J 313(Pt 1):343351

Melo SA, Luecke LB, Kahlert C, Fernandez AF, Gammon ST, Kaye J, LeBleu VS, Mittendorf EA, Weitz J, Rahbari N et al (2015) Glypican-1 identifies cancer exosomes and detects early pancreatic cancer. Nature 523:177-182

Mendonsa AM, Na TY, Gumbiner BM (2018) E-cadherin in contact inhibition and cancer. Oncogene 37:4769-4780

Meurer S, Wimmer AE, Leur EV, Weiskirchen R (2019) Endoglin trafficking/exosomal targeting in liver cells depends on $\mathrm{N}$-glycosylation. Cells 8:1-24 
Mi W, Gu Y, Han C, Liu H, Fan Q, Zhang X, Cong Q, Yu W (2011) O-GIcNAcylation is a novel regulator of lung and colon cancer malignancy. Biochim Biophys Acta 1812:514-519

Miyazono K, Heldin CH (1989) Role for carbohydrate structures in TGF- $\beta 1$ latency. Nature 338:158-160

Miyazono K, Thyberg J, Heldin CH (1992) Retention of the transforming growth factor- $\beta 1$ precursor in the Golgi complex in a latent endoglycosidase $\mathrm{H}$-sensitive form. J Biol Chem 267:5668-5675

Moustakas A, Heldin CH (2016) Mechanisms of TGF $\beta$-induced epithelial-mesenchymal transition. J Clin Med 5:63

Mukherjee P, Faber AC, Shelton LM, Baek RC, Chiles TC, Seyfried TN (2008) Thematic review series: sphingolipids. Ganglioside GM3 suppresses the proangiogenic effects of vascular endothelial growth factor and ganglioside GD1a. J Lipid Res 49:929-938

Nagae M, Kizuka Y, Mihara E, Kitago Y, Hanashima S, Ito Y, Takagi J, Taniguchi N, Yamaguchi $Y$ (2018) Structure and mechanism of cancer-associated $\mathrm{N}$-acetylglucosaminyl-transferase-V. Nat Commun 9(3380):1-12

Nickel J, Ten Dijke P, Mueller TD (2018) TGF- $\beta$ family co-receptor function and signaling. Acta Biochim Biophys Sin (Shanghai) 50:12-36

O'Brien DP, Sandanayake NS, Jenkinson C, Gentry-Maharaj A, Apostolidou S, Fourkala EO, Camuzeaux S, Blyuss O, Gunu R, Dawnay A et al (2015) Serum CA19-9 is significantly upregulated up to 2 years before diagnosis with pancreatic cancer: implications for early disease detection. Clin Cancer Res 21:622-631

Partridge EA, Le Roy C, Di Guglielmo GM, Pawling J, Cheung P, Granovsky M, Nabi IR, Wrana JL, Dennis JW (2004) Regulation of cytokine receptors by Golgi N-glycan processing and endocytosis. Science 306:120-124

Pellet-Many C, Frankel P, Jia H, Zachary I (2008) Neuropilins: structure, function and role in disease. Biochem J 411:211-226

Pinho SS, Figueiredo J, Cabral J, Carvalho S, Dourado J, Magalhaes A, Gartner F, Mendonfa AM, Isaji T, Gu J et al (2013) E-cadherin and adherens-junctions stability in gastric carcinoma: functional implications of glycosyltransferases involving $\mathrm{N}$-glycan branching biosynthesis, $\mathrm{N}$-acetylglucosaminyltransferases III and V. Biochim Biophys Acta 1830:2690-2700

Pinho SS, Reis CA (2015) Glycosylation in cancer: mechanisms and clinical implications. Nat Rev Cancer 15:540-555

Pinho SS, Reis CA, Paredes J, Magalhaes AM, Ferreira AC, Figueiredo J, Xiaogang W, Carneiro F, Gartner F, Seruca R (2009) The role of $\mathrm{N}$-acetylglucosaminyltransferase III and V in the post-transcriptional modifications of E-cadherin. Hum Mol Genet 18:2599-2608

Priglinger CS, Obermann J, Szober CM, Merl-Pham J, Ohmayer U, Behler J, Gruhn F, Kreutzer TC, Wertheimer C, Geerlof A et al (2016) Epithelial-to-mesenchymal transition of RPE cells in vitro confers increased beta1,6-N-glycosylation and increased susceptibility to galectin-3 binding. PLoS ONE 11(e0146887):1-25

Purchio AF, Cooper JA, Brunner AM, Lioubin MN, Gentry LE, Kovacina KS, Roth RA, Marquardt H (1988) Identification of mannose 6-phosphate in two asparagine-linked sugar chains of recombinant transforming growth factor- $\beta 1$ precursor. J Biol Chem 263:14211-14215
Regina Todeschini A, Hakomori SI (2008) Functional role of glycosphingolipids and gangliosides in control of cell adhesion, motility, and growth, through glycosynaptic microdomains. Biochim Biophys Acta 1780:421-433

Reily C, Stewart TJ, Renfrow MB, Novak J (2019) Glycosylation in health and disease. Nat Rev Nephrol 15:346-366

Robertson IB, Horiguchi M, Zilberberg L, Dabovic B, Hadjiolova K, Rifkin DB (2015) Latent TGF- $\beta$-binding proteins. Matrix Biol 47:44-53

Robertson IB, Rifkin DB (2016) Regulation of the Bioavailability of TGF- $\beta$ and TGF- $\beta$-Related Proteins. Cold Spring Harb Perspect Biol 8:1-25

Rodrigues JG, Balmana M, Macedo JA, Pocas J, Fernandes A, deFreitas-Junior JCM, Pinho SS, Gomes J, Magalhaes A, Gomes C et al (2018) Glycosylation in cancer: selected roles in tumour progression, immune modulation and metastasis. Cell Immunol 333:46-57

Sarkar TR, Battula VL, Werden SJ, Vijay GV, Ramirez-Pena EQ, Taube JH, Chang JT, Miura N, Porter W, Sphyris N et al (2015) GD3 synthase regulates epithelial-mesenchymal transition and metastasis in breast cancer. Oncogene 34:2958-2967

Schnaar RL, Kinoshita T (2015) Glycosphingolipids. In: Varki A, Cummings RD, Esko JD, Stanley P, Hart GW, Aebi M, Darvill AG, Kinoshita T, Packer NH et al (eds) Essentials of glycobiology, 3rd edn. Cold Spring Harbor, New York, pp 125-135

Sha X, Brunner AM, Purchio AF, Gentry LE (1989) Transforming growth factor $\beta 1$ : importance of glycosylation and acidic proteases for processing and secretion. Mol Endocrinol 3:10901098

Takeuchi H, Haltiwanger RS (2014) Significance of glycosylation in Notch signaling. Biochem Biophys Res Commun 453:235-242

Taniguchi N, Kizuka Y (2015) Glycans and cancer: role of N-glycans in cancer biomarker, progression and metastasis, and therapeutics. Adv Cancer Res 126:11-51

ten Dijke P, Goumans MJ, Pardali E (2008) Endoglin in angiogenesis and vascular diseases. Angiogenesis 11:79-89

Tu CF, Wu MY, Lin YC, Kannagi R, Yang RB (2017) FUT8 promotes breast cancer cell invasiveness by remodeling TGF- $\beta$ receptor core fucosylation. Breast Cancer Res 19(111):1-16

van Kooyk Y, Kalay H, Garcia-Vallejo JJ (2013) Analytical tools for the study of cellular glycosylation in the immune system. Front Immunol 4(451):1-6

Venkatachalam MA, Weinberg JM (2013) New wrinkles in old receptors: core fucosylation is yet another target to inhibit TGF- $\beta$ signaling. Kidney Int 84:11-14

Ventura E, Weller M, Macnair W, Eschbach K, Beisel C, Cordazzo C, Claassen M, Zardi L, Burghardt I (2018) TGF- $\beta$ induces oncofetal fibronectin that, in turn, modulates TGF- $\beta$ superfamily signaling in endothelial cells. J Cell Sci 131:209619

Wang M, Zhu J, Lubman DM, Gao C (2019) Aberrant glycosylation and cancer biomarker discovery: a promising and thorny journey. Clin Chem Lab Med 57:407-416

Wang X, Inoue S, Gu J, Miyoshi E, Noda K, Li W, Mizuno-Horikawa Y, Nakano M, Asahi M, Takahashi M et al (2005) Dysregulation of TGF- $\beta 1$ receptor activation leads to abnormal lung development and emphysema-like phenotype in core fucose-deficient mice. Proc Natl Acad Sci USA 102:15791-15796 
Wu MH, Chen YL, Lee KH, Chang CC, Cheng TM, Wu SY, Tu CC, Tsui WL (2017) Glycosylation-dependent galectin-1/neuropilin-1 interactions promote liver fibrosis through activation of TGF- $\beta$ and PDGF-like signals in hepatic stellate cells. Sci Rep 7 (11006):1-16

Xu P, Liu J, Derynck R (2012a) Post-translational regulation of TGF$\beta$ receptor and Smad signaling. FEBS Lett 586:1871-1884

Xu Q, Isaji T, Lu Y, Gu W, Kondo M, Fukuda T, Du Y, Gu J (2012b) Roles of N-acetylglucosaminyltransferase III in epithelial-to-mesenchymal transition induced by transforming growth factor beta1 (TGF- $\beta 1$ ) in epithelial cell lines. J Biol Chem 287:16563-16574

Xu Y, Uddin N, Wagner GK (2018) Covalent probes for carbohydrate-active enzymes: from glycosidases to glycosyltransferases. Methods Enzymol 598:237-265

Yang J, Antin P, Berx G, Blanpain C, Brabletz T, Bronner M, Campbell K, Cano A, Casanova J, Christofori G et al (2020) Guidelines and definitions for research on epithelial-mesenchymal transition. Nat Rev Mol Cell Biol 7:131

Yang Y, Dignam JD, Gentry LE (1997) Role of carbohydrate structures in the binding of $\beta 1$-latency-associated peptide to ligands. Biochemistry 36:11923-11932
Yu L, Hebert MC, Zhang YE (2002) TGF- $\beta$ receptor-activated p38 MAP kinase mediates Smad-independent TGF- $\beta$ responses. EMBO J 21:3749-3759

Zhang H, Meng F, Wu S, Kreike B, Sethi S, Chen W, Miller FR, Wu G (2011) Engagement of I-branching \{beta\}-1,6-N-acetylglucosaminyltransferase 2 in breast cancer metastasis and TGF- $\beta$ signaling. Cancer Res 71:4846-4856

Zhang L, Luo S, Zhang B (2016) The use of lectin microarray for assessing glycosylation of therapeutic proteins. MAbs 8:524-535

Zhang YE (2017) Non-Smad signaling pathways of the TGF- $\beta$ family. Cold Spring Harb Perspect Biol 9:1-18

Zhao $\mathrm{Y}$, Itoh S, Wang X, Isaji T, Miyoshi E, Kariya Y, Miyazaki K, Kawasaki N, Taniguchi N, Gu J (2006) Deletion of core fucosylation on $\alpha 3 \beta 1$ integrin down-regulates its functions. J Biol Chem 281:38343-38350

Zhao Y, Sato Y, Isaji T, Fukuda T, Matsumoto A, Miyoshi E, Gu J, Taniguchi N (2008) Branched N-glycans regulate the biological functions of integrins and cadherins. FEBS J 275:1939-1948 